\title{
Assessment and Recommendations for a Fossil Free Future for Track Work Machinery
}

\author{
Martina Zeiner ${ }^{1, *(\mathbb{D})}$, Matthias Landgraf ${ }^{1}\left(\mathbb{D}\right.$, Dieter Knabl $\left.{ }^{1} \mathbb{(}\right)$, Bernhard Antony ${ }^{2}$, Víctor Barrena Cárdenas ${ }^{2}$ \\ and Christian Koczwara ${ }^{3}$ \\ 1 Institute of Railway Engineering and Transport Economy, Graz University of Technology, Rechbauerstraße 12, \\ 8010 Graz, Austria; m.landgraf@tugraz.at (M.L.); dieter.knabl@tugraz.at (D.K.) \\ 2 Plasser \& Theurer, Johannesgasse 3, 1010 Vienna, Austria; bernhard.antony@plassertheurer.com (B.A.); \\ barrena880@gmail.com (V.B.C.) \\ 3 Plasser \& Theurer, Pummererstraße 5, 4021 Linz, Austria; Christian.Koczwara@plassertheurer.com \\ * Correspondence: martina.zeiner@tugraz.at; Tel.: +43-316-873-6218
}

Citation: Zeiner, M.; Landgraf, M.; Knabl, D.; Antony, B.; Barrena

Cárdenas, V.; Koczwara, C.

Assessment and Recommendations for a Fossil Free Future for Track Work Machinery. Sustainability 2021, 13, 11444. https://doi.org/10.3390/ su132011444

Academic Editor: Luca D’Acierno

Received: 16 September 2021

Accepted: 12 October 2021

Published: 16 October 2021

Publisher's Note: MDPI stays neutral with regard to jurisdictional claims in published maps and institutional affiliations.

Copyright: (c) 2021 by the authors. Licensee MDPI, Basel, Switzerland. This article is an open access article distributed under the terms and conditions of the Creative Commons Attribution (CC BY) license (https:/ / creativecommons.org/licenses/by/ $4.0 /)$.

\begin{abstract}
Current railway track work machinery is mainly operated with diesel fuel. As a result, track maintenance of Austrian Federal Railways (OeBB) amounts to nearly 9000 t $\mathrm{CO}_{2}$ equivalent per year according to calculations from Graz University of Technology. OeBB's total length of railway lines only accounts for $0.56 \%$ of the world's length of lines. This indicates huge potential for mitigating greenhouse gas emissions considering the need for track maintenance worldwide. Environmental concerns have led to the introduction of alternative drives in the transport sector. Until now, R\&D (Research \& Development) of alternative propulsion technologies for track work machinery has been widely neglected. This paper examines the possibility of achieving zero direct emissions during maintenance and construction work in railways by switching to alternative drives. The goal is to analyze alternative propulsion solutions arising from the transport sector and to assess their applicability to track work machinery. Research results, together with a calculation tool, show that available battery technology is recommendable for energy demands lower than $300 \mathrm{kWh}$ per construction shift. Hydrogen fuel cell technology is an alternative for energy demands higher than $800 \mathrm{kWh}$. For machinery with energy requirements in between, enhancements in battery technology are necessary and desirable for the coming years.
\end{abstract}

Keywords: track work machinery; sustainable track maintenance; alternative propulsion technologies in transport; zero direct emissions in track work machinery; green energy

\section{Introduction}

In regard to climate change, anthropogenic $\mathrm{CO}_{2}$ emissions play a crucial role. In order to limit a further rise in temperature, global goals to reduce greenhouse gas emissions (GHG) were defined in the Paris Agreement [1]. The European Green Deal should help achieve these goals and serves as a roadmap for creating a sustainable, competitive economy with the goal of reducing net greenhouse gas emissions to zero by 2050 [2].

Today, 94\% of the energy required for the European Union's (EU) transport sector still originates from oil resources [3]. Globally, the transport sector is responsible for around one quarter of $\mathrm{CO}_{2}$ emissions from fuel combustion, (wherein rail accounts for $4.2 \%$ ), another $38.4 \%$ arises from the energy industry's own use, commercial and public services, residential and others, and the remaining $36.9 \%$ originates from manufacturing industries and construction [4].

In 2009, an analysis of 40 countries showed that the global construction industry was responsible for $23 \%$ of the world's $\mathrm{CO}_{2}$ emissions across its entire supply chain [5]. Around $6 \%$ of the $23 \%$ are direct emissions from activities on construction sites, predominantly through the combustion of fossil fuels (mainly gasoline, diesel, other petroleum products, and light fuel oil) to power machinery and equipment. The remaining $94 \%$ are indirect 
emissions (e.g., energy needed for the provision of products). In the European Union, the share of national GHG emissions from construction non-road mobile machinery (NRMM) amounts to $1.06 \%$ on average [6]. In $2007,2 \%$ of the total $\mathrm{CO}_{2}$ emissions from transport in the European Union originated from construction equipment [7].

The share of GHG emissions of railway track work machinery is considered neither in statistics from the transport nor the construction sector. However, this sector should not be neglected. Current track work machinery is predominantly powered by diesel engines. As a result, track maintenance of the Austrian Federal Railways (OeBB) amounts to more than $8800 \mathrm{tCO}_{2}$ equivalent per year (Figure 1) according to calculations from the Institute of Railway Engineering and Transport Economy (Graz University of Technology).

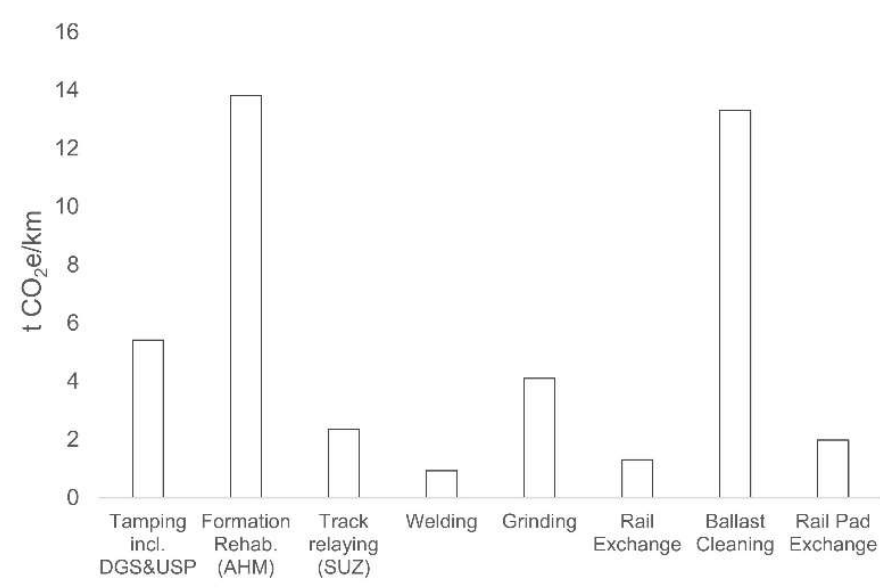

Includes transport, fuel consumption, material transport and production.

(a)

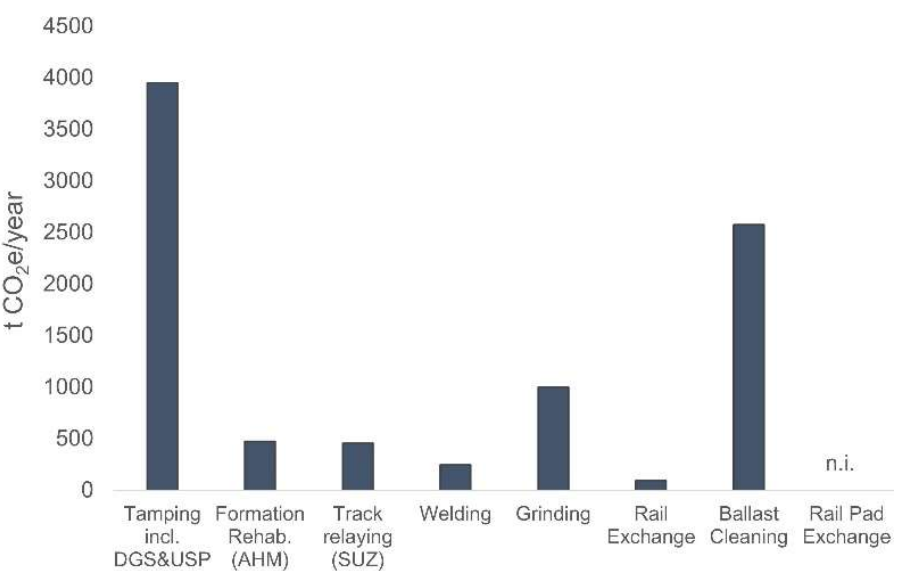

Lengths from Network Status Report (ÖBB-Infrastruktur AG, 2019).

(b)

Figure 1. GHG emissions of track maintenance of Austrian Federal Railways per km (a) and per year (b) according to calculations from the Institute of Railway Engineering and Transport Economy (Graz University of Technology).

The comparison of GHG of different track work (Figure 1a) shows that formation rehabilitation and ballast-cleaning machines have the highest impact per kilometer by far. Ballast-cleaning machines, for example, excavate the whole ballast bed, clean as much ballast as possible for on-site reuse, and add new ballast to renew the ballast bed completely. Thus, these machines are heavy, fuel intensive, and are slower in their working progress compared to other types of track work machinery.

In terms of annual GHG emissions (Figure 1b), tamping (including dynamic track stabilizing and a share of tamping of turnouts which is performed with track-bound work machinery) has the highest environmental impact. This is because tamping is by far the most frequently executed track work in Austria, with approximately $1000 \mathrm{~km}$ per year being done. Since this calculation does not consider conventional tamping of turnouts, it can be assumed that GHG emissions are even higher. Based on OeBB's overall passenger transport in 2019 [8] and specific emission values for different modes of transport in Austria [9], the following can be concluded: Austrian Federal Railways' annual track maintenance corresponds to roughly $6.1 \%$ of the overall passenger transport emissions for 2019 , which is equivalent to approximately 50 million $\mathrm{km}$ of direct car emissions or to direct emissions from 35,000 short distance flights. Moreover, the OeBB's total length of railway lines only accounts for $0.56 \%$ of the length of lines of the world's railway network [10]. Since track work trains operate in most countries around the world, this indicates that there is huge potential for mitigating GHG emissions.

Currently, various regulations applicable to diesel engine emissions to reduce pollutant emissions (i.e., carbon monoxide, hydrocarbons, NOx, PM) are in place around the world, some of which have been harmonized [11]. Although diesel drives have come under pressure, it is assumed that they will continue to be used in sectors such as railways [12]. 
On the contrary, local driving bans for diesel vehicles that might be imposed in the future could change tender conditions [13]. Furthermore, policies, political incentives, action plans and roadmaps have been introduced and (governmental) funds for scientific research have been received throughout the last decade in different regions worldwide (for detailed information compare Supplementary Material Review S1: regulative boundary conditions and environmental awareness). They aim to achieve the decarbonization of the transport sector and implementation of alternative propulsion technologies in order to ensure sustainable mobility in the future. These alternative solutions for conventional fossil fuels range from electrification over hydrogen-based solutions to gaseous fuels and biofuels to synthetic fuels (see Section 2.2).

In contrast to the transport sector, sustainable goals in the construction sector are less clear [6]. However, governments and stakeholders are increasingly aware of the pollution and emissions caused by the sector. Green procurement in the construction sector is being increasingly emphasized [14]. In order to have more sustainable construction sites, some countries are introducing legislative measures $[15,16]$, and the industry is also taking the initiative $[17,18]$.

Explicit decarbonization strategies developed by European governments or railways reflect the consciousness of reducing the environmental impact in the rail sector [12,19-26]. Most of these strategies aim to substitute diesel traction within the next 15 to 20 years. It is noteworthy that Norway and Switzerland have also set goals for track work construction machinery $[23,24]$.

In sum, the environmental impact of track work machinery is not to be neglected, neither in the rail nor in the construction sector. Procurements aiming to reduce carbon emissions or emission targets have an impact on the introduction of alternative drives. The vote on the EU climate law in October 2020 will probably lead to even more ambitious targets [27]. Considering climate targets set by decision-makers, it can be assumed that demand for zero emission rail vehicles and construction machinery will rise in the future, and that track work machinery will be subject to more stringent regulations in the near future as well. As track work trains are fuel-intensive, decarbonization could lead to the essential mitigation of environmental impacts, thus contributing to an ecological railway system.

Therefore, the goal of this study is to analyze different alternative propulsion technology solutions arising from the transport sector and assess their applicability to the railway sector and to track work machinery. It is the first study to focus on the area of track work machinery on a broad scale and to review alternative drives for track work machinery. The applied methods include a detailed literature review (which provides the necessary scientific knowledge to elaborate a cross-industry market analysis and understand technology trends) and a calculation tool that was developed for this research to help determine specific alternative drive solutions for different types of track work machinery (considering regional and constructional boundary conditions).

The literature analysis considers market-specific aspects and risk factors. It captures the technology trends of different propulsion technologies in different modes of transport, with a special focus on the rail and construction sector. It reviews the rail sector and construction sector-both influential for the application of new technology in the sector of track work machinery - in such detail that it is possible to derive solutions for alternative propulsion technology in the sector of track work machinery. These results are further transferred to the calculation tool CalCAS (Calculation of Comparison for Alternative Solutions). It is a tool that uses operating data from different types of track work machinery as well as information from relevant reports and publications, information from existing, publicly available data sources and input from experts, in order to provide the tool with the necessary scientific basis. The user can choose the battery and fuel cell type, a desired charging time as well as different shift lengths for a specific machinery. Consequently, electric energy demand, capacity and connection power for recharging are calculated automatically. The results of CalCAS are combined with a decision tree in order to identify 
the most suitable alternative drive solution for a specific type of track work machinery. Technical and regional constraints (e.g., availability of energy supply, such as electricity or hydrogen) are taken into account. Hence, CalCAS helps to determine machine-specific proposals for the preferred main power source and a possible alternative scenario for different shift lengths.

Finally, the paper provides guidelines and recommendations for alternative drive solutions for different track work machinery based on the results of the market analysis and the outputs of the calculation tool. The results and outputs must be reviewed in detail for different countries or when used by construction companies or track work production companies. This is the first major step towards more ecological solutions for track work machinery.

\section{Literature Review}

\subsection{Status Quo of Track Work Machinery}

Track work trains operated in most countries around the world are predominantly powered by diesel engines. GHG emissions due to fuel combustion of track work machinery are not included in current environmental statistics of the transport or construction sector and are widely ignored in environmental strategies. Decarbonization goals so far exist only in Norway and Switzerland [23,24]. Alternative propulsion technology in the sector of track work machinery is limited to a few models (Table 1).

Up to now, alternative solutions for track work machinery are mostly hybrid systems rather than stand-alone solutions. Smaller (lighter) track maintenance tools (e.g., portable tampers), which run on battery power alone are an exception to the above. Despite the fact that manufacturing companies are increasingly developing machinery with alternative propulsion systems, the variety of products is small compared to the amount of different track work machinery that exists.

Table 1. Overview of alternative powered track work machinery.

\begin{tabular}{|c|c|c|c|c|c|}
\hline & Manufacturer & Models & Power Source & Status-Quo & Source \\
\hline \multirow{11}{*}{ 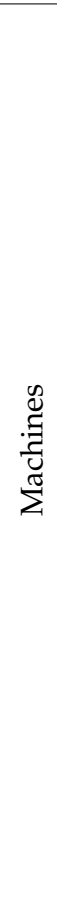 } & Geismar & $\begin{array}{l}\text { VMB-E (similar to MTW } \\
\text { of P\&T) }\end{array}$ & battery or catenary & offered in website portfolio & [28] \\
\hline & Geismar & $\begin{array}{l}\text { V2R-CGR maintenance } \\
\text { vehicle }\end{array}$ & diesel-battery & offered in website portfolio & {$[28]$} \\
\hline & Harsco & $\begin{array}{l}\text { Utility Track Vehicle } \\
\text { (UTV) }\end{array}$ & catenary-battery & $\begin{array}{c}\text { framework contract to supply } \\
\text { vehicles for DB }\end{array}$ & [29] \\
\hline & Linsinger & Rail milling train & fuel cell & & {$[30]$} \\
\hline & Plasser \& Theurer & BDS $2000 \mathrm{E}^{3}$ & diesel-catenary & \multirow{2}{*}{$\begin{array}{l}\text { First-ever hybrid track work } \\
\text { machinery, in operation at work } \\
\text { sites in Switzerland and Austria }\end{array}$} & \multirow{2}{*}[31,32]{} \\
\hline & Plasser \& Theurer & $\begin{array}{l}09-4 \times E^{3} \text { Dynamic } \\
\text { Tamping Express }\end{array}$ & diesel-catenary & & \\
\hline & Plasser \& Theurer & HTW $100 \mathrm{E}^{3}$ & diesel-battery & $\begin{array}{c}\text { first-ever battery powered } \\
\text { vehicle in the industry (2017) }\end{array}$ & {$[31-33]$} \\
\hline & Plasser \& Theurer & $\begin{array}{l}\text { Unimat 09-32/4S } \\
\text { Dynamic } E^{3}\end{array}$ & diesel-catenary & \multirow{2}{*}{$\begin{array}{c}\text { in operation at work sites in } \\
\text { Austria }\end{array}$} & \multirow[t]{2}{*}{ [31] } \\
\hline & Plasser \& Theurer & Unimat $09-4 \times 4 / 4 \mathrm{SE}^{3}$ & diesel-catenary & & \\
\hline & Railcare & Multi-Purpose Vehicle & battery & $\begin{array}{l}\text { recently unveiled for operation } \\
\text { in Sweden }\end{array}$ & {$[34,35]$} \\
\hline & Windhoff & Rail transport wagon & $\begin{array}{c}\text { not yet defined } \\
\text { (battery or fuel cell) }\end{array}$ & $\begin{array}{l}\text { contract to deliver three dual } \\
\text { power vehicles }\end{array}$ & [36] \\
\hline
\end{tabular}


Table 1. Cont.

\begin{tabular}{|c|c|c|c|c|c|}
\hline & Manufacturer & Models & Power Source & Status-Quo & Source \\
\hline \multirow{8}{*}{$\frac{n}{8}$} & Geismar & $\begin{array}{l}\text { Battery-Powered } \\
\text { Portable Tamper }\end{array}$ & battery & & [28] \\
\hline & Geismar & $\begin{array}{l}\text { Battery-Powered } \\
\text { Abrasive Rail Saw }\end{array}$ & battery & & [28] \\
\hline & Robel & Rail Drilling Machine & battery & \multirow{5}{*}{$\begin{array}{c}\text { first prototypes showcase } \\
\text { In-House Exhibition in 09/2019 }\end{array}$} & \multirow{5}{*}{ [37] } \\
\hline & Robel & Rail Band Saw & battery & & \\
\hline & Robel & Impact Wrench & battery & & \\
\hline & Robel & Vertical Tamper & battery & & \\
\hline & Robel & Rail Cutter & battery & & \\
\hline & Robel & Rail loading system & supercapacitor & $\begin{array}{l}\text { prototype presentation at IAF } \\
\qquad 2017\end{array}$ & [38] \\
\hline
\end{tabular}

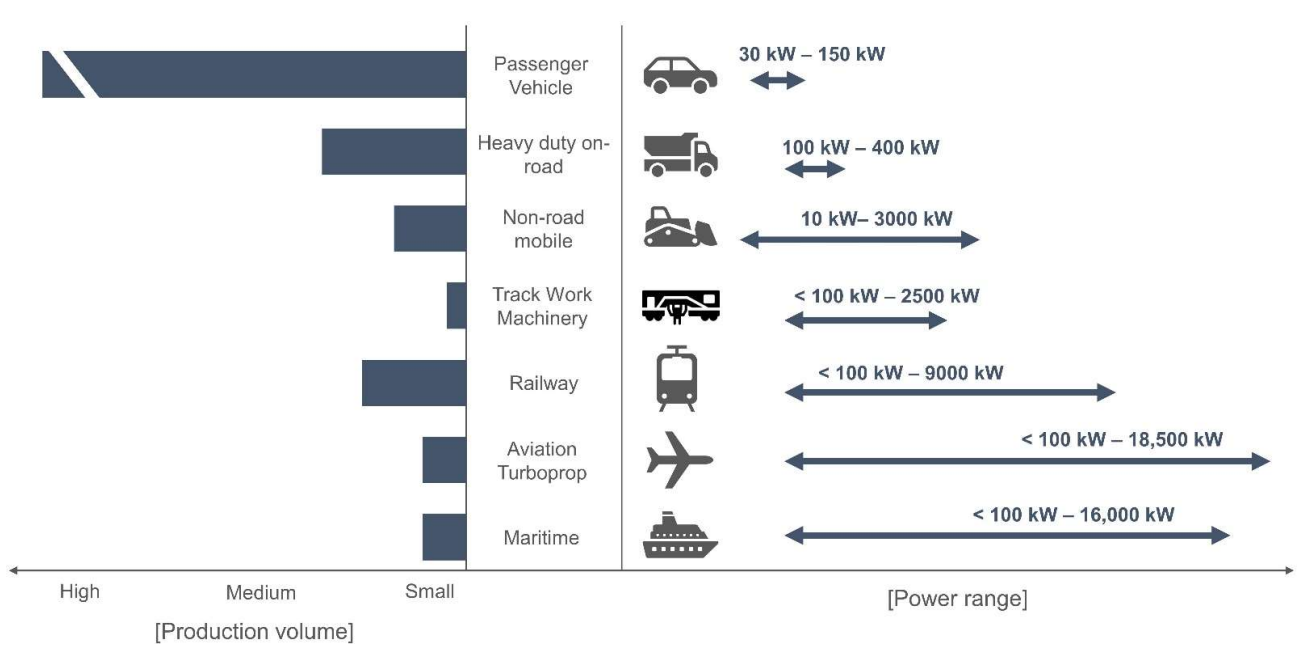

Figure 2. Power range and production volume of different modes of transport based on information from various sources [39,41-47].

Track Work Machinery Compared to Other Modes of Transport

Track work machinery are tailor-made products. Additionally, the lack of interoperability in railways (e.g., different railway electrification systems) and the fact that track work machinery operates in different countries around the world complicates the application of one single alternative propulsion solution. Some machinery (e.g., welding machines) require peak power for a very short time, while others work on continuous power. The fact that duty cycles and operation patterns distinguish between different types of machinery is also valid for NRMM, as reviewed by Lajunen [39] and influences the choice of the alternative drive solution. Furthermore, track work machinery shows huge differences in working power. Installed nominal power of different machine types from Plasser \& Theurer ranges from less than $100 \mathrm{~kW}$ for material logistics like MFS 100 to above $2000 \mathrm{~kW}$ required by RU800S used for track renewal and ballast bed cleaning [40]. It can be concluded that the power range of track work machinery lies within the area of several modes of transport (Figure 2). Thus, it requires a cross-market analysis to understand the opportunities and challenges of a specific alternative propulsion technology and learn from the trends and experience of other modes of transport.

Track work machinery is a niche product. The literature does not refer to it specifically and it is unclear whether it is assigned to the rail or the construction sector. Today, the majority of diesel locomotives are diesel-electric [48], while construction machinery (like 
track work machinery) is mostly diesel-hydrostatic or diesel-hydrodynamic [49]. Thus, the technological concepts for powertrains and transmissions used in the construction sector could be applied to track work machinery. Regarding the primary power source, track work machinery is highly influenced by market trends in the rail sector. This is because implementing alternative solutions depends on the infrastructure for supplying energy (e.g., charging or refueling). Therefore, a special focus must be put on rail vehicles and construction machinery.

\subsection{Overview of Alternative Propulsion Technologies}

Today, there is a strong trend towards electrification via on-board energy storage systems (ESS) using batteries. The automotive sector, in particular, drives battery technology development in the passenger transportation sector [50]. In the public transportation sector, electrification has been state-of-the-art (e.g., in rail transport: overhead catenary, third rail) for decades.

In addition to batteries, fuel cells also allow for electrification of vehicles. Hydrogen is very well suited for electricity generation with fuel cells (FC) - in fuel cell electric vehicles (FCEV), hydrogen usually combines with oxygen in a fuel cell, consequently generating electricity that powers an electric motor [51]. Just like batteries they can provide propulsive power or work as a range-extender [52].

Lithium-ion (li-ion) battery technologies, namely LMO (lithium-manganese-oxide), LFP (lithium-iron-phosphate), NCA (lithium-nickel-cobalt-aluminum-oxide) and NMC (lithium-nickel-manganese-cobalt-oxide), as well as conventional lead-acid and nickelmetal hybrid batteries are the dominant battery technologies in the field of passenger vehicles [50-53]. LFP are also popular in buses [54]. However, current automotive technology is not fully transferable to other sectors, notably due to technical properties [55-57]. For instance, ESS in the rail sector face high requirements in terms of ambient temperature [13], specific energy/energy density which influence on-board weight/space [58,59], as well as safety and approval regulations (e.g., fire protection, tunnel safety) [13,60,61].

According to the alternative drive rail data pool (which was elaborated for the purpose of this study, see Supplementary Material Table S1: alternative drive rail data pool), the dominating battery technology in railway vehicles is li-ion based, notably NMC, LFP, or LTO (lithium-titanate). Nickel-cadmium and lead-acid batteries are also used but less common (see Supplementary Material Table S1). NCA technology, which is popular in the automotive sector, has not been identified for any railway project (see Supplementary Material Table S1). It is assumed that this is due to currently used li-ion technology in railways which perform better in terms of safety than NCA [62]. NMC batteries offer high energy density and high specific energy as opposed to LFP and LTO [62]. LFP and LTO outperform NMC in terms of thermal stability [62]. A top advantage of LFP is its low cost [40].

Battery technologies for excavators, wheel and underground loaders comprise NMC [63-66], Nano-NMC [67,68], LFP [65-69], NCA [67] and LTO batteries [66-70]. Battery technology, specifically for heavier machinery-similar to heavy-duty on-road vehicles-still requires further development [71].

According to the information from currently available trainsets (see Supplementary Material Table S1), characteristics of hybrid components show the following: Fuel cell trains with a traction power of $380-700 \mathrm{~kW}$ require a fuel cell power range from 130 to $400 \mathrm{~kW}$ and battery capacity from 20 to $240 \mathrm{kWh}$. Similar information can be found in the literature [13], where the maximum power of fuel cells is $500 \mathrm{~kW}$ for freight and passenger trains, and maximum battery capacity is $310 \mathrm{kWh}$. For construction machinery, battery capacity varies with machinery type. Battery capacity in small excavators $(<7 \mathrm{t})$ ranges from 20 to $60 \mathrm{kWh}[63,67,72,73]$. Standard excavators $(7 \mathrm{t}<45 \mathrm{t})$ require a higher capacity, but usually less than $300 \mathrm{kWh}[64,69,73,74]$.

Gaseous fuels represent a further development of conventional fuels and can be used in internal combustion engines (ICE) [75]. One type is liquefied petroleum gas (LPG) 
which "is obtained during natural gas and oil extraction, or as a by-product of being manufactured during the refining of petroleum" [75]. When obtained from fossil fuels (natural gas), they come in form of CNG (compressed natural gas) or LNG (liquefied natural gas), [76]. Bio-derived alternatives are sourced from renewables or feedstock through different processes (anaerobic digestion, gasification or through methanization of hydrogen made via electrolysis) [77]. Alternative fuels like biodiesel or ethanol are known as biofuels and produced from biomass [78].

Another substitute for diesel are the so-called synfuels-they are specifically designed and can be produced from renewable sources [79]. They can be obtained from different sources, such as natural gas (Gas to Liquid, GtL), biomass (Biomass to Liquid, BtL), vegetable oils and fats (Hydrogenated Vegetable Oil, HVO) or through the conversion of hydrogen to hydrogen-based fuels, like synthetic methane or ammonia [80,81].

\subsection{Road Transport}

An analysis of research and innovation projects in Europe from 2007 onwards reflects the aforementioned trends in decarbonizing transport. The analysis shows that the road sector is certainly the most developed sector compared to others (e.g., aviation, railways and maritime) in terms of technology project distribution of alternative propulsion technologies. Yet, only a small number of research projects in the transport sector have been validated or implemented. [82]

\subsubsection{Passenger Vehicles}

Gaseous fueled vehicles, battery electric vehicles (BEV) and fuel cell electric vehicles (FCEV) are commercially available technologies $[54,77,83]$. Contrary to BEV, FCEV were only entering the market with a ratio FCEV:BEV of 1:250 in 2019 [51]. Major markets for BEV are China, USA and Europe [51], while the global leader in the deployment of fuel cell cars is the US [52]. In 2020, alternative drives in the EU's passenger car fleet captured less than $5 \%$ of the total [84]. Data on newly registered cars in the EU show that BEV and FCEV are gaining popularity, whereas there is a decline in CNG and LPG [84].

\subsubsection{Heavy-Duty on-Road Vehicle}

Alternative solutions for heavy-duty on-road vehicles are almost all restricted to LPG, CNG and LNG [85] with their share being much lower than in the car sector $[83,86]$. Governmental initiatives worldwide or pilot projects for captive fleets with hydrogen solutions [81] and registrations in the EU and European sales show a growing trend towards electric rechargeable technology [84]. However, freight heavy-duty trucks ( $>15$ tonnes) need further development, e.g., fast power charging and advanced battery capacity [51].

\subsection{Rail Sector}

More than $60 \%$ of the world's railway network is not electrified [87], and around $70 \%$ of the world's locomotive fleet $(200,000)$ operates on non-electrified lines [88]. This shows the high demand for alternative drives, especially in countries with a low electrification rate and segments which tend to be operated with diesel. These segments are often shunting, where the use of overhead lines is not possible [89], branch lines and freight corridor [90-93]. However, the field of application (e.g., power/range required) and boundary conditions (e.g., electricity grid, regulations) influence the choice of any alternative propulsion technology. Currently available solutions in the rail sector can be summarized as follows:

Bi-mode trains are either powered from diesel or catenary [58-94]. They are increasingly commercially available and becoming state-of-the-art, which is reflected in the fact that the 300th unit has already been manufactured by Alstom [95]. A major reason for their success is the fact that they do not require additional infrastructure compared to hybrid solutions. 
Hybrid solutions are equipped with an energy converter (e.g., internal combustion engine, fuel cell, catenary), usually designed for average power output and an energy storage system (e.g., battery) $[13,58,96]$. The use of supercapacitors is currently restricted to urban rail applications [97-99].

The ESS can be used to recuperate braking energy (a big advantage compared to pure diesel vehicles), cover load peaks (e.g., perform acceleration solely with ESS device and thereby cut fuel consumption/emissions) or bridge non-electrified sections [13,100,101]. Therefore, hybrids are well suited for last-mile shunting and start and stop operations, like on branch lines with frequent stops $[13,100,101]$.

Current hybrid solutions in railways (see Supplementary Material Table S1) are vehicles that run on diesel-battery, fuel cell-battery (so-called hydrails) or catenary-battery power. Current tenders (see Supplementary Material Table S1), a declining diesel rolling stock market [102], the aforementioned political measures and the fact that electrification is not always viable (n)or technically feasible indicate a further rise in alternative drives.

According to the information from the alternative drive rail data pool (see Supplementary Material Table S1 and Figure 3), the following can be concluded: Ongoing activities show a trend towards alternative solutions in the aforementioned segments. This concerns, for example, the introduction of battery electric multiple units (BEMU) or hydrails on branch lines. Austrian Federal Railways is also performing trials with hydrails and BEMUs. The multiple unit segment has proved to be the most mature segment (Figure 3) for the application of hybrid solutions (especially hydrails) with many ongoing projects in central Europe and Japan. The share of lighthouse projects of hybrid locos/shunters or hybrid multiple units as well as LNG/CNG fueled locos is still small. Gas-powered solutions are present in North American and Eastern European countries (e.g., LNG locos by Russian Railways). Synfuel application is limited to tests (e.g., by Deutsche Bahn). The pie chart in Figure 3 underlines the fact that most of the projects in the rail sector (depicted in the bar graph) are still at a very early stage of development or not yet implemented. Bi-mode solutions, although increasingly popular, are not part of this study.
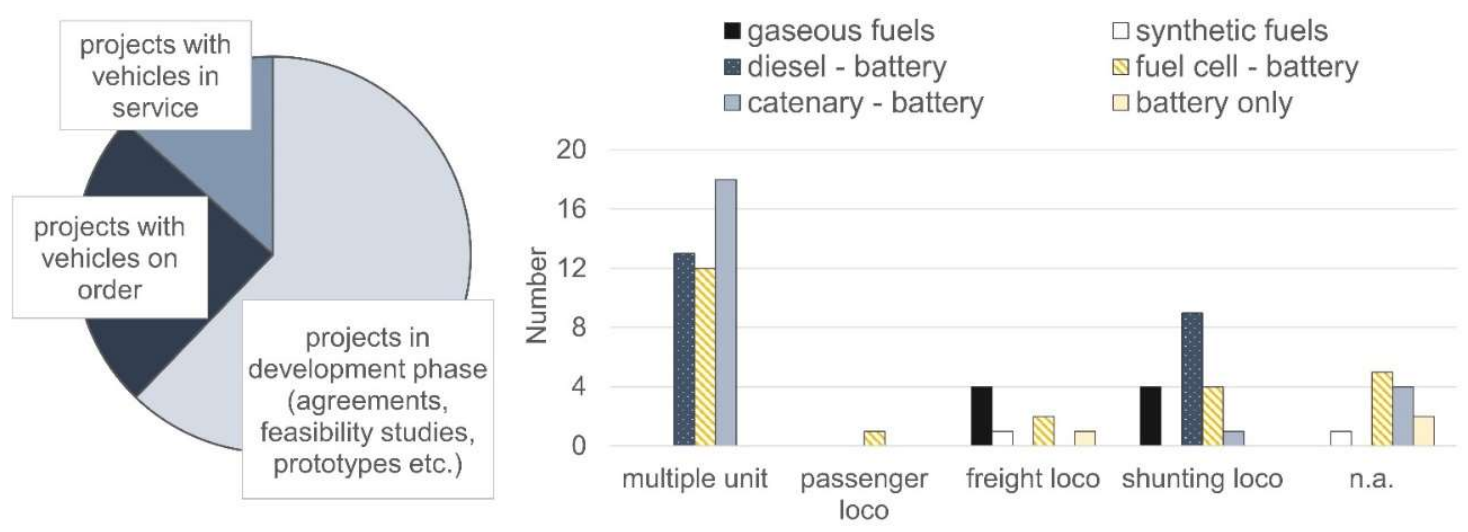

Figure 3. On-going activities in the rail sector with regard to alternative propulsion technologies (bi-mode solutions excluded) according to the alternative drive rail data pool (see Supplementary Material Table S1).

\subsection{Construction Sector}

Alternative drives along with machine efficiency (e.g., optimization of transmission), process efficiency, and operation efficiency represent the four pillar-approach by the Committee for European Construction Equipment (CECE) to counteract market pressure and decrease the carbon footprint for NRMM [7]. Hybridization of construction machinery (in this case diesel in combination with an ESS) of excavators, wheel loaders and mining loaders, has existed for two decades [18,103-105]. They work on the principle of using kinetic energy/energy regeneration from the machine's swinging action or boom down motion which charge the ESS and (help) power the engine system [7]. The energy saving potential of hybrid excavators and wheel loaders lies between 10 and 35\% [104]. 
While electrification is mostly limited to electric construction machinery with cable, handheld equipment or smaller machines [106], the literature $[6,39,49,106]$ and market research (Figure 4 ) shows that companies are increasingly developing electric machinery. Nevertheless, alternative drives, regardless of which type, are at a very early stage of development. They are only just entering the market, most of which are prototypes. One exception are forklifts, where hydrogen fuel cell applications are a mature technology [77,81]. Prototypes for hydrogen-electric excavators are under development [107]. Gaseous fuel application/gas engines are a mature technology but restricted to compact sweepers and tractors [108].

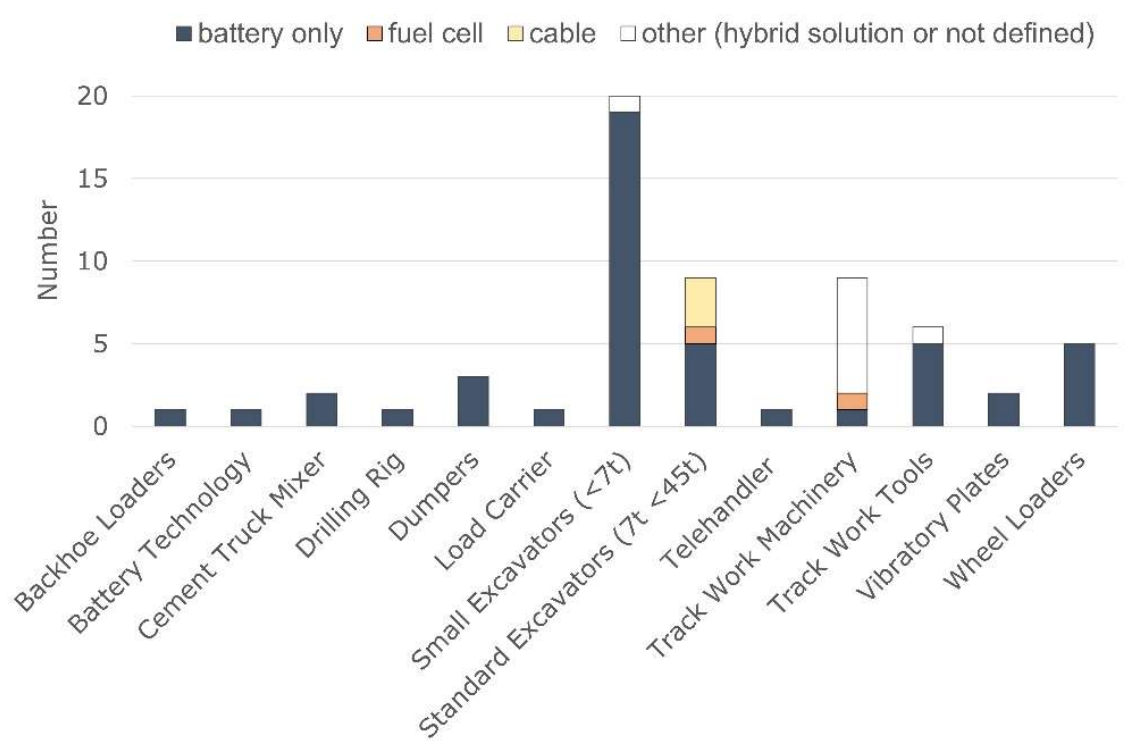

Figure 4. Pilot projects and prototypes in the construction sector with regard to alternative propulsion technologies (diesel-battery hybrids excluded) based on data from [73,74,109].

\subsection{Aviation}

The aviation sector is also committed to reducing $\mathrm{CO}_{2}$ and considering innovative solutions, which is, for instance, reflected in certain goals of the International Air Transport Association [57]. Rather than using hydrogen or batteries for main engines, solutions for onboard power demands or runway taxiing are being developed and tested $[77,81]$. However, flights with the first-ever fully electric cargo plane are scheduled for this year [110]. Biomassderived fuels (bio-jet) have been trialed on commercial and military flights for the last decade [111]. Hydrogen-based fuels are viewed as a good alternative due to the drawbacks of pure hydrogen or electricity, such as weight issues [54,112].

\subsection{Maritime}

Regulations which limit the sulfur content in ship fuel that are being implemented by organizations such as the International Maritime Organization prove that the maritime sector is also committed to reducing emissions [113]. However, alternative technology is in its infancy. Long-term solutions are seen in LNG and advanced biofuels, hydrogen and ammonia or hydrogen-based synthetic liquid, due to drawbacks of pure hydrogen or electricity $[54,57,77,81]$. Similar to the aviation sector, hydrogen and battery solutions are being primarily considered for in-port operation or auxiliary tasks [51-77], except for local ferries or vessels. While the first commercial fuel cell ferry (with $2 \times 300 \mathrm{~kW}$ shaft motor and $100 \mathrm{kWh}$ battery for boost power) was only developed in 2020 [114], 166 battery powered vessels are already in operation globally [113]. Cruise ships (which are in port for around $40 \%$ of their operating time) increasingly use electric shore power for energy supply at berth [115]. 


\subsection{Consolidation and Comparison}

It can be observed that all modes of transport are committed to reducing emissions and are increasingly considering alternative propulsion technologies. Experience from the rail and construction sector can thus be partly transferred to track work machinery.

In comparison to the rail sector, battery-electric only technology is much more established in the construction sector, but limited to electric construction machinery with cables, handheld equipment, or smaller machines. By contrast, fuel cell technology is at a very early stage of development (with the exception of forklifts). The battery range used in railways is comparable to that of heavier construction machinery, whereas Nano-NMC batteries were not able to be identified for rail vehicles. Very few models with alternative drives exist for track work machinery (Table 1). Similar to the rail sector, solutions for track work machinery tend toward bi-mode and hybrid systems rather than stand-alone solutions. Smaller (lighter) track maintenance tools, which run on battery power alone, are manufactured by Geismar and Robel (e.g., portable tampers, tools for replacing a closure rail or rail loading system).

\subsubsection{Opportunities}

The main advantages of electrified vehicles are their higher energy-efficiency and decreased noise pollution compared to internal combustion engines [51]. They have zero tailpipe emissions since GHG emissions are accounted for in the production steps of electricity [54]. A huge advantage of electrification and green energy is that less air and noise pollution is emitted at construction sites [6]. Moreover, electric construction machinery needs less maintenance [6] and studies on excavators show that electric machinery could have a lifetime that is $50 \%$ longer compared to diesel machinery [106].

The opportunities of hydrogen lie in zero local emissions when used in fuel cells (waste product is water) and higher efficiency compared to ICE plus higher specific energy and higher driving ranges (over $500 \mathrm{~km}$ ) compared to batteries [53]. A big advantage of gaseous fuels is their possible use in established ICE and the fact that they can be transported on existing CNG and LNG refueling infrastructure [54].

\subsubsection{Challenges}

A general challenge is the lack of charging and refueling infrastructure [116]. Largescale deployment of battery or fuel cell technology in vehicles requires specific infrastructure, e.g., hydrogen distribution logistics, refueling stations or overhaul $[117,118]$. When transferring technology from the construction sector to track work machinery, the following must be considered: track work takes place on "moving" construction sites, which complicates recharging/refueling compared to conventional construction machinery.

Another challenge is posed by the end-of-life of components, like batteries $[13,119]$. Currently, legislative measures are taken regarding recyclability/end-of-life, e.g., reviewing of Battery Directive 2006/66/EC [51], or other similar regulative documents [120].

Carbon intensity depends on the electricity mix of the specific country-higher efficiency in using brown energy reduces environmental impacts (e.g., exhaust cleaning), whereas the aim should be to use green energy in order to contribute to reducing the environmental impact.

An environmental challenge for hydrogen is the production process. Two thirds of today's hydrogen production comes from natural gas [81]. Other eco-friendlier production processes are being explored. They range from electrolysis (established alternative which however only accounts for $2 \%$ of the production process and depends on the electricity mix) to solar energy to split $\mathrm{H}_{2} \mathrm{O}$ thermally (still at laboratory scale) and modified biomass gasification trials at Graz University of Technology [81,121]. A further challenge is related to space requirements for storage [122] due to the low volumetric energy density of hydrogen [123].

Recently, contradictory statements on GHG emissions and particulate matter (PM) have been published for gaseous fuels [124]. Until now it was believed that they decrease 
emissions $[77,125,126]$. However, recent studies state the opposite. Despite these contradictory statements, further (mid-term) use is still expected in the transport sector due to high energy densities [103], e.g., in railways [127,128] or aviation [111]. Critics fear that synfuels relocate the problem rather than present a solution, especially where a great amount of fuel is required, like in railways [13]. This is because of energy-intensive production processes and the exploitation of resources [80,129]. Another challenge for synfuels is large-scale implementation with low costs and renewable energy [79].

\subsection{Summary}

Solutions for alternative propulsion technologies are still in their infancy, regardless of the mode of transport. This can be attributed to the aforementioned barriers such as lack of technology verifications (insecurity for customers), limited product availability (economies of scale), lack of regulatory structures, safety and security concerns, on-board weight and space requirements, lack of infrastructure including refueling, recharging, equipment for overhaul and impacts on life cycle (resources, electricity mix, recyclability). Another barrier is the economic feasibility of the development phase [130]. It can be assumed that these barriers will be overcome in the future, due to continuously rising tenders and procurements as well as technological progress and more stringent regulative boundary conditions.

With regard to track work machinery, the process of research and development of alternative propulsion technologies and their application has just started. While trends to certain alternative solutions in certain other transport segments can already be observed, the question as to which alternative drive solutions would be the best for track work machinery remains unsolved and depends on the type of machinery.

The next chapters of the research presented in this paper therefore depict the area of track work machinery on a broad scale for the first time. They cover various boundary conditions of construction operation as well as technical and regional constraints (e.g., vehicle properties, energy supply infrastructure) with the aim of identifying the best solutions and contributing to the achievement of zero emissions within the rail and construction sector.

\section{Materials and Methods-CalCAS}

This study establishes a machine-specific calculation tool for a scenario-based key performance indicator. CalCAS (Calculation of Comparison for Alternative Solutions) is a tool to determine the optimum alternative solution for specific types of track work machinery. Within this research, we obtain results for twelve types of track-bound work machinery. CalCAS was developed using Microsoft Excel. General technical data as well as user specific input data are required to calculate the electric energy demand, capacity and connection power for recharging different types of machinery (Figure 5). Finally, we combine the results with a decision tree to help determine the optimum alternative propulsion technology considering regional and technical constraints (since track work machinery is being operated globally).

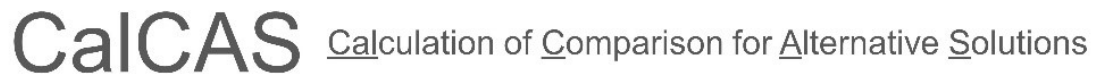

Input data
User specific: type of battery and fuel cell (to choose
from list), charging time, shift length
Technical data
Density of battery type, DoD (Depth of Discharge),
energy capacity and density of hydrogen, weight and
size of hydrogen storage
Machine data: working speed, fuel consumption etc.
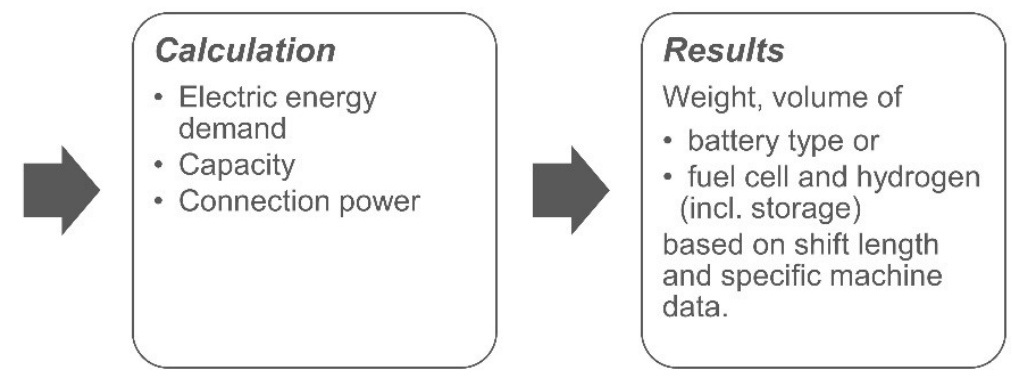

Figure 5. CalCAS Calculation of Comparison for Alternative Solutions for Track Work Machinery. 


\subsection{Limitations}

In the research, we focus on battery and hydrogen fuel cell solutions, since findings in our study show that gaseous or synfuels are not considered as sufficient solutions to mitigate environmental impacts in the long-term. Currently, the calculation tool includes battery technologies that could be identified as dominant in the rail and construction sector (i.e., LTO, NMC, Nano-NMC and LFP). NCA batteries were included as well, mainly because of their popularity in the automotive sector and assumptions that safety issues may be overcome in the future. Technical input data is based on technologies that are currently available.

\subsection{Methodoloy of CalCAS}

The methodology of CalCAS (Figure 5) can be described as follows: First, the user can choose the battery and fuel cell type, a desired charging time as well as usual shift lengths for a specific type of machinery. Transport from/to the construction site are to be assessed additionally. Consequently, electric energy demand, capacity and connection power for recharging is calculated automatically (see detailed description in Section 3.2.2). The tool uses operating data from different kinds of track work machinery in order to calculate the electric energy demand. For some machinery, the electric energy was obtained from fuel and power consumption measurements. In the event that information was unavailable, the average diesel fuel consumption was estimated. The result is displayed as weight and volume of the battery or fuel cell and required hydrogen based on shift length and machinery data. In addition to the calculation of weight and volume of various energy sources, the tool also displays the ratio weight of energy to the weight of track work machinery. Sensitivity analyses for different scenarios can be obtained by varying the input data. This tool can be extended to include future calculations with updated input and technical data.

\subsubsection{Input Data and Technical Data}

Technical data contains efficiency values of ICE and electric powertrains, several decreasing factors (e.g., a safety cushion to have some reserve energy after planned work, usable battery capacity or DoD-Depth of Discharge) as well as basic properties of fuels (density of diesel and hydrogen). These values are customized for specific applications. Dataset lists for available battery types and fuel cell types with specific properties count as technical data and are input data needed for further calculations. User specific input data describes the scenario which is calculated. Values which need to be set accordingly are listed in Table 2.

Table 2. User specific input data required for calculation of different scenarios in CalCAS.

\begin{tabular}{cc}
\hline Parameter & Description \\
\hline Charging time $[\mathrm{h}]$ & $\begin{array}{c}\text { In the case of battery operation or hybrid usage, this value defines the desired } \\
\text { charging time of the battery. }\end{array}$ \\
\hline Shift multiplier & $\begin{array}{c}\text { Multiplies working hours to multiple shifts based on standard shift length of eight } \\
\text { hours (which represents a standard scenario). }\end{array}$ \\
\hline FC workload & $\begin{array}{c}\text { Fuel cells are usually designed to work at highest efficiency which is achieved at a } \\
\text { specific load. This parameter defines the desired continuous workload of the FC. }\end{array}$ \\
\hline Time share of battery-only mode & $\begin{array}{r}\text { The calculation model can consider hybrid mode operation (so far: battery-catenary, } \\
\text { hydrogen-catenary hybrids not yet included). This value sets the working time which } \\
\text { should be reached with battery-only mode, it defines the battery capacity. }\end{array}$ \\
\hline Battery factor $[1 / \mathrm{h}]$ & $\begin{array}{r}\text { This value defines the proportion of the FC power to battery capacity in case of FC } \\
\text { only mode. By definition. the unit is } 1 / \mathrm{h} .\end{array}$ \\
Battery type & $\begin{array}{r}\text { In CalCAS the user can choose from different types of batteries. Their properties are } \\
\left.\text { listed in a separate datasheet and include volumetric energy density [m }{ }^{3} / 100 \mathrm{kWh}\right] \\
\text { and gravimetric energy density }[\mathrm{Wh} / \mathrm{kg}] .\end{array}$ \\
\hline
\end{tabular}


Table 2. Cont.

\section{Parameter}

FC type
Description

The above stated is also true for the FC type. The separate datasheet contains FC specific values such as volumetric energy density $\left[\mathrm{m}^{3} / 100 \mathrm{kWh}\right]$, gravimetric energy (or power) density [kW/kg] and FC efficiency. CalCAS uses the cell type PEMFC (proton exchange membrane fuel cells) as this is the dominating fuel cell technology for transport applications currently [52].

\subsubsection{Calculation/Equation}

The input and technical data allows for calculating the results for specific boundary conditions for a specific type of machinery. Calculations can be carried out for battery mode and hydrogen mode, or if parameterized, for hybrid mode. The calculation is based on the fuel consumption of the particular machine. Intermediate steps consider efficiencies, the average power and the average electric energy demand per shift. This is the basis for calculating the battery size (Equation (1)) or fuel cell power (Equation (2)).

$$
\begin{gathered}
\mathrm{BC}=\left(\left(\mathrm{t}_{\mathrm{wps}} \times \mathrm{f}_{\mathrm{s} \_ \text {mult }}\right) /\left(\mathrm{BC}_{\mathrm{use}} \times \eta_{\text {el_PT }}\right)\right) \times\left(\mathrm{FC}_{\mathrm{av}} / 1000\right) \times \mathrm{EC}_{\text {Diesel }} \times \rho_{\text {Diesel }} \times \eta_{\mathrm{ICE}} \\
\mathrm{BC} \ldots \text { required battery capacity }(\text { rated capacity })[\mathrm{kWh}] \\
\mathrm{P}_{\mathrm{FC}}=\left(\mathrm{FC}_{\mathrm{av}} /\left(1000 \times \mathrm{WL}_{\mathrm{FC}}\right)\right) \times \mathrm{EC}_{\text {Diesel }} \times \rho_{\text {Diesel }} \times \eta_{\mathrm{ICE}} \\
\mathrm{P}_{\mathrm{FC}} \ldots \text { required fuel cell power }(\text { rated power })[\mathrm{kW}]
\end{gathered}
$$

Parameters:

$t_{\mathrm{wps}}$ : working hours per eight-hour shift $[\mathrm{h}]$

$\mathrm{f}_{\mathrm{S} \_ \text {mult }}$ : shift multiplier [1]

$\mathrm{BC}_{\mathrm{use}}$ : factor to describe usable battery capacity [1]

$\eta_{\mathrm{el} \_\mathrm{PT}}$ : efficiency of electric powertrain [1]

$\mathrm{FC}_{\mathrm{av}}$ : average fuel consumption $[1 / \mathrm{h}]$

$\mathrm{EC}_{\text {Diesel }}$ : energy capacity of diesel $[\mathrm{kWh} / \mathrm{kg}]$

$\rho_{\text {Diesel }}$ : density of diesel $\left[\mathrm{kg} / \mathrm{m}^{3}\right]$

$\eta_{\text {ICE }}$ : efficiency of internal combustion engine [1]

WLFC: workload fuel cell [-]

In an additional step, CalCAS computes the weight of the battery and fuel cell as well as hydrogen needed based on the results from Equations (1) and (2), including specific input data. The weight of the battery plus the weight of the fuel cell powerpack represent the weight ready for use, i.e., including housing and battery management system (BMS), etc. The weight of hydrogen storage is based on the ratio between the weight of hydrogen and the weight of the storage system. CalCAS does not include an estimation of the weight of traction converters needed to manage the electricity flow from the alternative power source to the traction motors, as well as other necessary electric equipment (transformers, wiring, etc.).

Furthermore, CalCAS also calculates the maximum charging power. This is necessary to verify the maximum grid power required for a full charge within the desired charging time. 


\section{Results and Discussion}

The objective of this study is to provide machine-specific proposals for a preferred main power source and a possible alternative scenario for different shift lengths. The assessed machinery is clustered into four classes according to their engine power and electric energy demand for an eight-hour shift:

- Cluster low: $<300 \mathrm{kWh}$

- Cluster med1: $<800 \mathrm{kWh}$

- Cluster med2: $<1200 \mathrm{kWh}$

- Cluster high: $\geq 1200 \mathrm{kWh}$

Note that welding machines are not assorted to any cluster as they do not demand continuous power, but rather require high peak currents for a short period of time.

Figure 6 presents an excerpt of detailed calculation results for shift length scenarios of eight and $48 \mathrm{~h}$ for different clusters. The illustrated battery types represent standard li-ion technology, which is state-of-the-art in the transport sector. They represent the lowest and highest specific energy and therefore the highest (LTO) and lowest (NCA) weight per electric energy demand of the analyzed types. Results for fuel cell technology include powerpack, hydrogen, as well as the hydrogen storage unit.

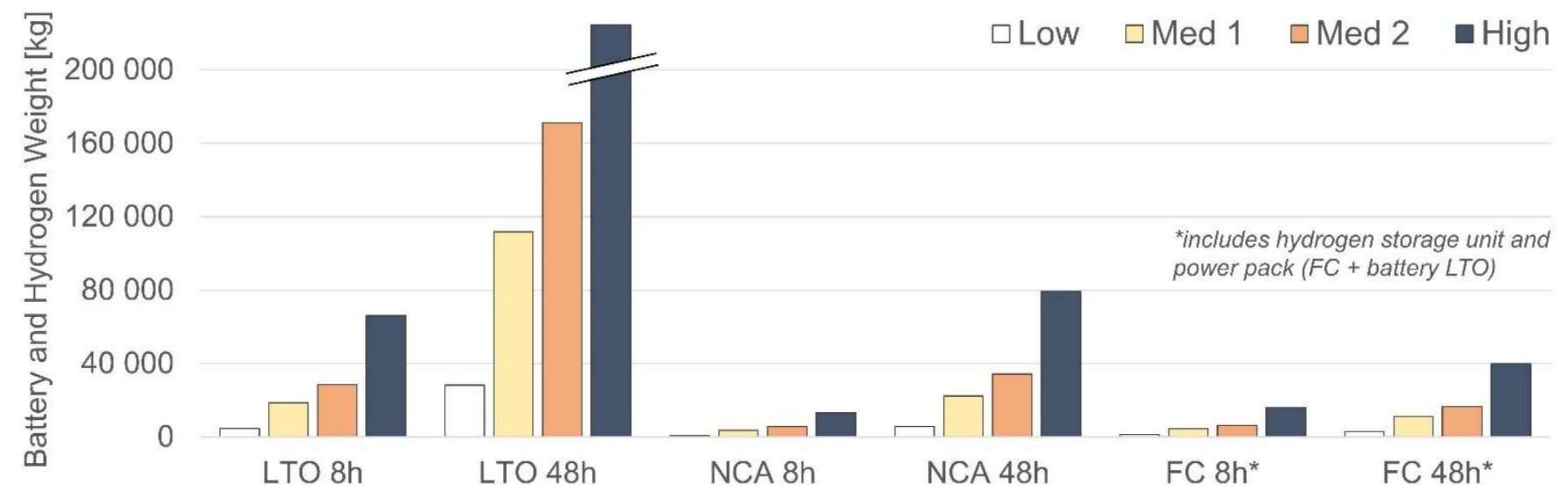

Figure 6. Calculation results for cluster low, med1, med2 and high.

These results show that fuel cell technology is ideal for heavy machinery with higher energy demands and for higher shift lengths. Shorter shift lengths for machinery with medium and high energy demands can also be covered with NCA battery technology. This is based on the following assumptions: either the safety of NCA battery technology will increase and become comparable to currently used li-ion technology in railways, namely NMC, LFP or LTO, which perform better in terms of safety [62], or another battery technology with a similar specific energy to that of NCA can be developed.

Due to the fact that track work machinery are tailor-made products and operate in different countries under different boundary conditions, the results of CalCAS require additional considerations. The decision tree (Figure 7) helps to determine the optimum alternative propulsion technology considering regional and technical constraints. 


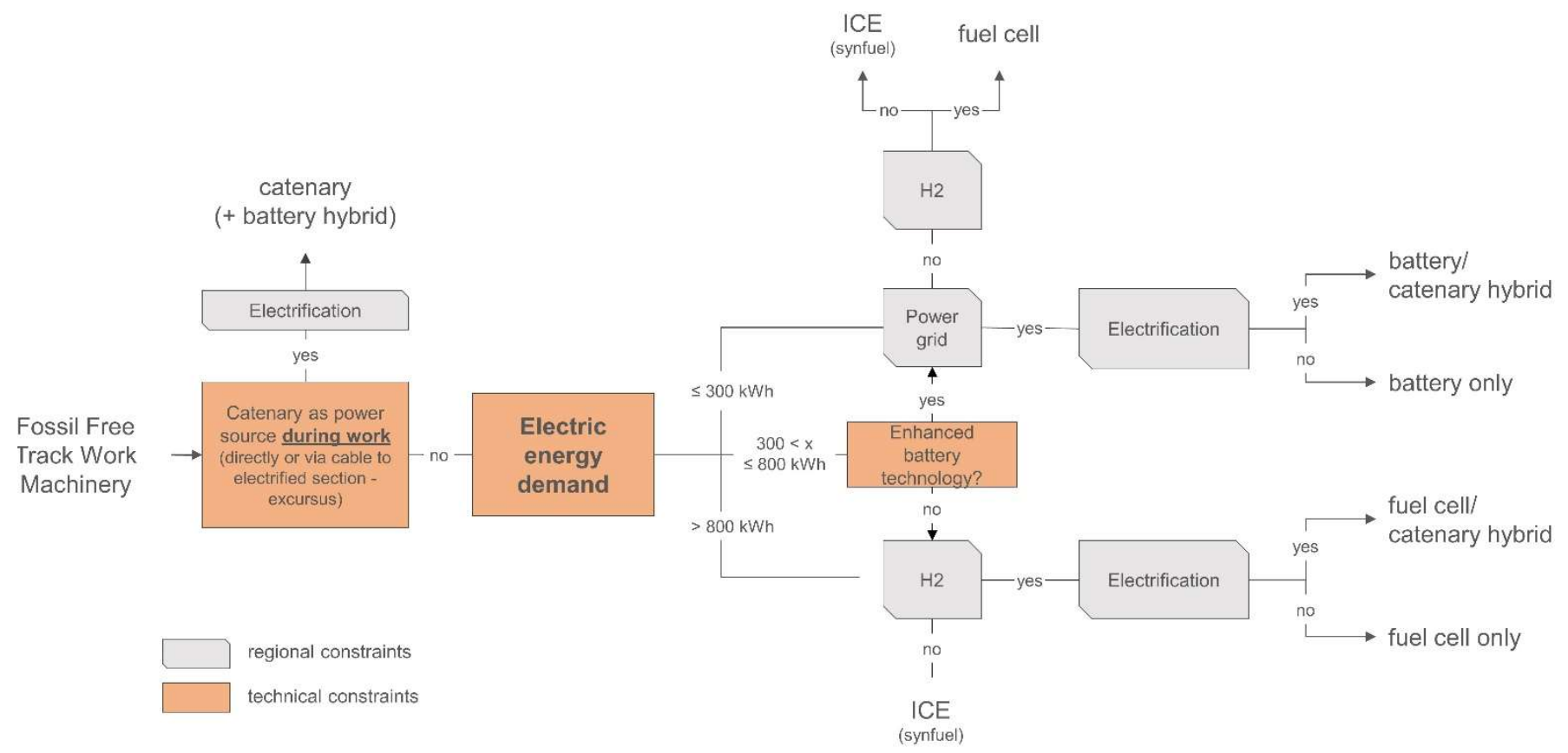

Figure 7. Decision tree for determination of the optimum alternative propulsion technology considering regional and technical constraints.

The first technical question should be whether power from the catenary can be used during track work or not, since using electrical energy as a primary power source (directly from the power grid) is the most efficient solution. However, some maintenance procedures require the power to be switched off during work for safety reasons. The choice for the alternative solution then depends on the energy required by the specific machinery, which is calculated by CalCAS. In the event that catenary-sourced power is not an option, which in this specific case also means that it is not possible to recharge from the catenary during an eight-hour shift, the results and recommendations are as follows:

On-board battery technology is the preferred solution for track work machinery which requires less than $300 \mathrm{kWh}$ of energy per shift. When performing track work on an electrified network, battery-catenary hybrids are ideal. They increase autonomy with the extra benefit of electrified transport to and from the construction site. In regions without an available power grid, alternative solutions could include hydrogen fuel cell technology or an internal combustion engine with synfuels, although the latter are arbitrary (compare Section 2.8.2). Hydrogen fuel cell technology is recommendable for machinery that requires more than $800 \mathrm{kWh}$ of energy per shift without the possibility for recharging during the duration of the shift. This is based on calculations which consider the average size and weight of a battery block that does not exceed the maximum freight car payload/allowed axle load. Wherever electrification is available, hybridization with a catenary should also be considered for fuel cell technology. For machinery with energy requirements in between, either more advanced battery technology is needed due to weight issues, or the machinery should be equipped with fuel cell technology. The decision tree shows that the choice of any alternative solution depends on regionally specific boundary conditions such as the availability of electrification, power grids and hydrogen.

The main objective of this study is to define machine-specific proposals for a preferred main power source and a possible alternative scenario (Table 3). 
Table 3. Machine-specific proposals for an eight-hour shift.

\begin{tabular}{|c|c|c|}
\hline Cluster $^{1}$ & Machine Type & Preferred Main Power Source \\
\hline \multirow{2}{*}{ Low $(<300 \mathrm{kWh})$} & Catenary Inspection & Battery \\
\hline & Material Logistics & Battery \\
\hline \multirow{4}{*}{ Med1 (<800 kWh) } & Measuring Vehicle ( $\leq 60 \mathrm{~km} / \mathrm{h}$ working speed) & Battery $^{2}$ \\
\hline & Ballast distributing \& profiling & Battery/Fuel Cell ${ }^{2}$ \\
\hline & $\begin{array}{c}\text { Structure Conservation Vehicle (non-stationary } \\
\text { work mode) }\end{array}$ & Battery/Fuel Cell ${ }^{2}$ \\
\hline & Stabilisation & Battery/Fuel Cell ${ }^{2}$ \\
\hline \multirow{2}{*}{$\operatorname{Med} 2(<1200 \mathrm{kWh})$} & Measuring Vehicle (60-100 km/h working speed) & Battery/Fuel Cell ${ }^{3}$ \\
\hline & Universal Tamping Machine & Battery/Fuel Cell ${ }^{3}$ \\
\hline \multirow{4}{*}{$\operatorname{High}(\geq 1200 \mathrm{kWh})$} & Track Renewal and Laying & Fuel Cell \\
\hline & Ballast Cleaning & Fuel Cell \\
\hline & Formation Rehabilitation & Fuel Cell \\
\hline & Ballast Cleaning & Fuel Cell \\
\hline Misc. & Welding Machine & Battery \\
\hline
\end{tabular}

${ }^{1}$ Clusters are based on engine power and electric energy demand for an eight-hour shift. ${ }^{2}$ Currently, fuel cell technology would be the recommended solution, but development in battery technology will/may allow for battery in mid-term future. ${ }^{3}$ Battery technology could be a possible alternative for Med 2 if recharging from catenary is possible during the shift.

The outputs of CalCAS (Table 3) for an eight-hour shift show the following:

On-board battery technology is the preferred solution for track work machinery of cluster low as well as welding machines (considering that the energy demand for one shift of welding is less than $100 \mathrm{kWh}$ [40]). Welding machines may be equipped additionally with supercapacitors as this technology is predestined for high peak currents [131]. However, the time required for a welding action is by far longer than the usual time period for supercapacitors mentioned in Bégun and Frackowiak [132]. Fuel cells are a possible alternative for cluster low and welding machines. They would guarantee higher autonomy regarding range and shift lengths.

Cluster med1 (with energy requirements between 300 and $800 \mathrm{kWh}$ ) could also be equipped with battery technology. This would reduce the range and increase weight and charging time essentially in any case. Therefore, machinery from cluster med 1 would either require more advanced battery technology due to weight issues, or should be equipped with fuel cell technology.

Hydrogen fuel cell technology is recommendable for machinery that requires more than $800 \mathrm{kWh}$ of energy. Hence, fuel cell technology best meets the electrical energy demand of machinery from cluster med2 and high. Battery technology may be a possible alternative for cluster med 2 if recharging from a catenary is possible during the shift, which could be the case for tamping machines with a catenary hybrid. Often, tamping machines work on different sections of a line during one shift, which is why the catenary can be used when driving to the next section. Other alternative scenarios for cluster med 2 and high could be ICE with synfuels, as battery technology is not an option (specifically for cluster high) due to the weight, range, and recharging time.

Note that the results in Table 3 are based on the electric energy demand for an eighthour shift. A change in shift lengths could lead to a different preferred main power source. Should the shift length increase and recharging is unable to be performed during the shift, battery technology may no longer be an option for some machinery. By contrast, if the shift length for a formation rehabilitation machine decreases from eight to two hours, it can be assumed that the electric energy will decrease enormously. However, such a short shift length is inefficient, both from an economic and operational perspective.

The main challenge of the evaluated track work machinery is the lack of infrastructure for recharging batteries and refueling hydrogen as well as battery and fuel cell aging. One 
challenge for charging stations is to provide sufficient connection power, which is the crucial parameter for the recharging time (e.g., if big track machinery needs to be recharged within hours, the required charging power would exceed $1000 \mathrm{~kW}$ ). Hydrogen applications for smaller machines shows constraints regarding space for hydrogen storage as although hydrogen itself is light, it has a very low volumetric density. Stationary infrastructure for recharging and refueling must provide sufficient track lengths for long track work machineries. For both power sources, it would be ideal to have access to on-site/mobile recharging or refueling. This would require either mobile recharging/refueling stations or exchangeable tenders. On-site recharging/refueling would guarantee a high level of autonomy as recharging/refueling infrastructure might not be available in mid-term future, especially for hydrogen applications.

Depending on different technical and regional constraints, this research can be expanded to include any other country considering specific regional conditions and work train fleets. Moreover, the results can be used as a guideline for a more sustainable railway system and support in strategic decision-making. Construction companies could obtain valuable decision-making support when expanding or refurbishing their maintenance and renewal fleets in the context of a low-emission railway system. Infrastructure managers can improve and adapt migration strategies for fossil-free work trains and associated recharging and refueling infrastructure. Track work production companies can then adjust their portfolio of zero emission work trains with respect to technical and regional constraint, in order to provide their customers with the very best ecological solution.

Although this paper can provide guidelines and recommendations for alternative drive solutions for different track work machinery, the following aspects are not taken into account:

First, the calculation tool is restricted to fossil free solutions. Further developments of internal combustion engines or alternative fuels are not considered by the authors, as they are not considered to mitigate environmental impacts in the long-term. However, regional constraints might limit the choice of any alternative solution and might not allow for solutions other than optimized ICE with alternative fuels.

Secondly, the infrastructure provision plays a crucial role in the decision-making process and the final choice. In the case of the proposed results, it requires recharging or refueling facilities which supply sustainable energy at best—something that might not be available in a specific region.

Thirdly, the data used in CalCAS is based on the current energy consumption of the different track work machinery and does not consider efficiency optimization of engine technologies. Enhancements in ICE technology might lead to better efficiency and consequently less energy consumption, which could affect the proposed results. Furthermore, constructional constraints (shift lengths and the like) differ from country to country and would need to be adapted accordingly.

The findings of this paper, in particular the outputs of CalCAS together with the decision tree, are a first major step towards more eco-friendly solutions for track work machinery. It must be noted that these findings serve as a decision support. Final decisions about the choice of any alternative solution need to be made on a case-by-case basis.

\section{Conclusions}

Today, track work machinery still relies heavily on fossil fuels. Our study shows that even within Austrian Federal Railways (OeBB) alone, track maintenance operations amount to nearly $9000 \mathrm{t} \mathrm{CO}_{2}$ equivalent per year. Switching to alternative drives for track work machinery could contribute to reducing emissions and reaching zero direct emissions in the rail and construction sector. Being aware of that, OeBB were one of the first to support R\&D in that field by operating track work machinery with alternative propulsion technology at Austrian work sites (see Table 1).

Despite barriers to the market uptake of alternative drives (such as technology currently available, a lack of infrastructure, and higher costs due to scalability, the lack of clear 
goals and little demand), stakeholders in the rail and construction sector are aware of the need to reduce environmental impacts. In combination with technological progress, this will lead to a further rise in alternative drives.

Alternative drives, i.e., emission/fossil free solutions for track work machinery, are in their infancy. The benefits include fewer GHG emissions, less noise pollution, or higher efficiency. Research shows that the technological concepts for powertrains and transmissions used in the construction sector may be applicable to track work machinery. Regarding the primary power source, track work machinery is highly influenced by market trends in the rail sector. This is because implementing alternative solutions depends on the infrastructure for supplying energy (e.g., charging or refueling).

An alternative drive does not automatically mean it is fossil-free or emission-free. Alternative liquid fuels face significant challenges (high demand for primary energy, contradictory findings on emissions, concerns regarding synfuels, etc.). Battery and hydrogen applications depend on the electricity mix as well as on the production process and endof-life (recycling) of their components. Nonetheless, in terms of mitigating environmental impacts, they are considered to have a great deal of potential.

The outputs of CalCAS shows that on-board battery technology is the preferred solution for track work machinery requiring less than $300 \mathrm{kWh}$ of energy per shift. By contrast, hydrogen fuel cell technology is recommendable for machinery that requires more than $800 \mathrm{kWh}$ of energy per shift. Machinery with energy requirements in between will either necessitate more advanced battery technology due to weight issues, or the machinery will need to be equipped with fuel cell technology. The decision tree further shows that the choice of any alternative solution will depend on regionally specific boundary conditions such as the availability of electrification, power grids and hydrogen.

This study offers a first broad scale introduction to alternative propulsion systems for track work machinery with recommendations for the best solution for different kinds of machinery to reduce direct emissions in the future. However, emissions not only occur during the operation of track working machinery, but also arise throughout the whole life cycle. Future research should therefore consider the emissions caused during vehicle production and take a closer look at the end-of-life of different components.

Supplementary Materials: The following are available online at https:/ / www.mdpi.com/article/10 $.3390 /$ su132011444/s1, Review S1: regulative boundary conditions and environmental awareness, Table S1: alternative drive rail data pool.

Author Contributions: Conceptualization, M.Z., M.L., D.K., B.A., V.B.C. and C.K.; methodology, M.Z., M.L. and D.K.; software, M.Z., M.L., D.K. and V.B.C.; validation,: M.Z., M.L., D.K., B.A., V.B.C. and C.K.; formal analysis, M.Z., M.L. and D.K.; investigation,: M.Z., M.L., D.K., V.B.C. and C.K.; resources, B.A., V.B.C. and C.K.; data curation, M.Z., M.L. and D.K.; writing-original draft preparation, M.Z., M.L. and D.K.; writing—review \& editing, M.Z., M.L., D.K., B.A., V.B.C. and C.K.; visualization, M.Z., M.L. and D.K.; supervision, M.L. and B.A.; project Administration, M.L. and B.A. All authors have read and agreed to the published version of the manuscript.

Funding: Open Access Funding by the Graz University of Technology.

Institutional Review Board Statement: Not applicable.

Informed Consent Statement: Not applicable.

Data Availability Statement: Not applicable.

Conflicts of Interest: The authors declare no conflict of interest.

\section{References}

1. UNFCCC. The Paris Agreement. Available online: https://unfccc.int/process-and-meetings/the-paris-agreement/the-parisagreement (accessed on 19 August 2021).

2. European Commission. A European Green Deal. Available online: https://ec.europa.eu/info/strategy/priorities-2019-2024/ european-green-deal_de (accessed on 14 October 2020). 
3. European Commission. Non-Road Mobile Machinery (NRMM) Emissions-Impact of the COVID-19 Crisis. Available online: https:/ / ec.europa.eu/growth/content/non-road-mobile-machinery-nrmm-emissions-impact-covid-19-crisis_en (accessed on 5 October 2020).

4. International Energy Agency IEA, International Union of Railways UIC. Railway Handbook 2017-Energy Consumption and CO2 Emissions. Available online: http:/ / www.uic.org/ (accessed on 5 October 2021).

5. Huang, L.; Krigsvoll, G.; Johansen, F.; Liu, Y.; Zhang, X. Carbon emission of global construction sector. Renew. Sustain. Energy Rev. 2018, 81, 1906-1916. [CrossRef]

6. Ragonès, M.P.; Vafiadis, I.; Eriksen, C. Zero Emission Construction Sites Status 2019 (Bellona Foundation). Available online: https:/ / bellona.org/publication/zero-emission-construction-sites-status-2019 (accessed on 5 October 2021).

7. Committee for European Construction Equipment (CECE), European Agricultural Machinery (CEMA). CECE and CEMA Optimising Our Industry 2 Reduce Emissions. Available online: https: / /www.cece.eu/news/new-brochure-cece-and-cemaoptimising-our-industry-2-reduce-emissions (accessed on 5 October 2021).

8. ÖBB-Holding AG; ÖBB-Werbung GmbH. Zahken Daten Fakten ÖBB Kompakt 2019/20. Vienna. Available online: https: // konzern.oebb.at/dam/jcr:b17c14a2-d8a3-4d3c-8a40-912cbeefa6ab/OEBB_Zahlen_2020-2_de_web.pdf (accessed on 5 October 2021).

9. Umweltbundesamt. Emissionskennzahlen Datenbasis 2019. Available online: https://www.umweltbundesamt.at/fileadmin/ site/themen/mobilitaet/daten/ekz_pkm_tkm_verkehrsmittel.pdf (accessed on 21 July 2021).

10. International Union of Railways UIC. Railway Statistics-Synopsis. Available online: https://uic.org/IMG/pdf/uic-railwaystatistics-synopsis-2021.pdf (accessed on 5 October 2021).

11. DieselNet. Emission Standards: Europe: Nonroad Engines. Available online: https://www.dieselnet.com/standards/eu/ nonroad.php\#rail (accessed on 19 October 2020).

12. Smith, K. Do hydrogen and battery trains mean the end for diesel traction? Int. Railw. J. 2020, 60, $18-21$.

13. Pertl, P.; Gyurica, M.; Trattner, A.; Vopava, J.; Kienberger, T.; Zauner, A.; Böhm, H.; Tichler, R.; Wancura, H.; Veit, P.; et al. HYTRAIL Hydrogen Technology for Railway Infrastructure; HyCentA Research GmbH and Consortium: Graz, Austria, 2019.

14. Kadefors, A.; Lingegård, S.; Uppenberg, S.; Alkan-Olsson, J.; Balian, D. Designing and implementing procurement requirements for carbon reduction in infrastructure construction-International overview and experiences. J. Environ. Plan. Manag. 2021, 64, 611-634. [CrossRef]

15. Bund, E.V. Non-Road Mobile Emission Sources. Available online: http://www.sootfreecities.eu/sootfreecities.eu/public/ measure/non-road-mobile (accessed on 11 August 2020).

16. Borrás, J. World's First: Zero Emission Electric Construction Site. Available online: https://cleantechnica.com/2020/04/09 /worlds-first-zero-emission-electric-construction-site/ (accessed on 6 September 2021).

17. Williams, N.; Pennini, A.; Eames, M. Industry and Vehicle Manufacturers Join Forces to Develop Cleaner, Safer Vehicles. Available online: https: / / www.icmm.com/en-gb/news/2018/icsv_pr (accessed on 2 September 2020).

18. Volvo Construction Equipment. The Construction Climate Challenge. Available online: https://constructionclimatechallenge. com/about/ (accessed on 2 September 2020).

19. Prießnitz, M.; Gerstenmayer, T. The end of fossil fuels ÖBB Personenverkehr AG. In The End of Fossil Fuels; UIC Workshop Zürich: Zürich, Switzerland, 2019.

20. Zasiadko, M. Two Dutch Provinces Want to Shift to Zero-Emission Trains by 2035. Available online: https://www.railtech.com/ rolling-stock/2018/11/06/two-dutch-provinces-want-to-shift-to-zero-emission-trains-by-2035/ (accessed on 20 October 2020).

21. Railway Pro. Hungary Launches Battery-Electric Train Procurement. Available online: https://www.railwaypro.com/wp/ hungary-launches-battery-electric-train-procurement/ (accessed on 20 October 2020).

22. Zasiadko, M. Hybrid Conversion of Diesel Trains in Ireland. Available online: https://www.railtech.com/rolling-stock/20 20/07/27/hybrid-conversion-of-diesel-trains-in-ireland/?utm_source=newsletter\&utm_medium=email\&utm_campaign= Newsletterweek2020-31\&gdpr=accept\&gdpr=accept (accessed on 20 October 2020).

23. Oommen, S. The Norwegian railway reform. In The End of Fossil Fuels; UIC Workshop Zürich: Zürich, Switzerland, 2019.

24. Kramer, U. Center of Competence-Energy storage. In The End of Fossil Fuels; UIC Workshop Zürich: Zürich, Switzerland, 2019.

25. Alstom/Eversholt: Wasserstoff-Zug für UK. Der Eisenbahningenieur. 2018. Available online: https://www.alstom.com/de/pressreleases-news / 2019/1/alstom-und-eversholt-rail-praesentieren-einen-neuen-wasserstoffzug-fuer (accessed on 5 October 2021).

26. Zasiadko, M. Deutsche Bahn to Become CARBON Neutral by 2050. Available online: https://www.railtech.com/policy/2020/0 9/07/deutsche-bahn-to-become-carbon-neutral-by-2050/?utm_source=newsletter\&utm_medium=email\&utm_campaign= Newsletterweek2020-37 (accessed on 12 October 2020).

27. European Parliament. EU Climate Law: MEPs Want to Increase 2030 Emissions Reduction Target to 60\%. Available online: https:/ / www.europarl.europa.eu/news/en/press-room/20201002IPR88431/eu-climate-law-meps-want-to-increase-20 30-emissions-reduction-target-to-60 (accessed on 14 October 2020).

28. Geismar. Featured Products. Available online: https://geismar.com/?lang=en (accessed on 6 September 2021).

29. Barrow, K. Harsco to supply up to 56 hybrid maintenance vehicles to DB. Int. Railw. J. 2019. Available online: https:// www.railjournal.com/regions/europe/harsco-to-supply-up-to-56-battery-electric-maintenance-vehicles-to-db/ (accessed on 5 October 2021). 
30. Linsinger Maschinenbau GmbH. World's First Rail Re-Profiling without Emissions. Available online: https:/ /www.linsinger. $\mathrm{com} /$ portfolio/rail-milling-train-mg11-hydrogen/ (accessed on 6 September 2021).

31. Uhlenhut, A. Elektrische effizienz. Regionalverkehr 2018, 1, 55-57.

32. Wenty, R. Ökologische Innovation für die Gleisinstandhaltung. Deine Bahn 2016, 4, 14-17.

33. Kreisel. Kreiselelectric. Available online: https://energytalk.info/MediaCache/0/354849/KREISELELECTRICSYSTEMSsmallPräsentation.pdf (accessed on 23 July 2021).

34. Barriault, A.; Battley, T. Advanced Safety System for Advanced Battery Technology. MDEC. 2019. Available online: https: / / mdec.ca/2019/S5P2_Epiroc_Batteries.pdf (accessed on 5 October 2021).

35. Railcare. Battery Vacuum Excavator. Available online: https://www.railcare.se/wp-content/uploads/2020/11/MPV_screen_v3 .pdf (accessed on 6 September 2021).

36. Windhoff. WINDHOFF to Deliver 3-Section Works Train to VGF Frankfurt. Available online: https://www.windhoff.de/index. php/windhoff-to-deliver-3-section-works-train-to-vgf-frankfurt/?lang=en (accessed on 6 September 2021).

37. Hölzlwimmer, T. Battery technology-The drive power of the future in track construction. EI Eisenb. Available online: https: //railway-news.com/wp-content/uploads/2020/04/ROBEL-Battery-Technology.pdf (accessed on 5 October 2021).

38. Klee, B. Rail Replacement as a Maintenance Benchmark. Available online: https://www.semanticscholar.org/paper/Railreplacement-as-a-maintenance-benchmark-Klee/a9fc31ba83f4fc9a8eb0fac910b6557832fa5c5f (accessed on 5 October 2021).

39. Lajunen, A.; Suomela, J.; Pippuri, J.; Tammi, K.; Lehmuspelto, T.; Sainio, P. Electric and hybrid electric non-road mobile machinery-Present situation and future trends. In Proceedings of the EVS 2016-29th International Electric Vehicle Symposium, Montreal, QC, Canada, 19-22 June 2016; Volume 8, pp. 172-183.

40. Plasser \& Theurer; Vienna, Austria. Personal Communication, 2020.

41. GESAMP (IMO/FAO/UNESCO-IOC/UNIDO/WMO/IAEA/UN/UNEP Joint Group of Experts on the Scientific Aspects of Marine Environmental Protection). Estimates of Oil Entering the Marine Environment from Sea-Based Activities. Rep. Stud. GESAMP No. 75. p. 96. Available online: https://www.researchgate.net/publication/308631658_estimates_of_oil_entering_the_ marine_environment_from_sea-based_activities (accessed on 5 October 2021).

42. Focus Online. China: Siemens Baut Stärkste Lok der Welt. Available online: https://www.focus.de/finanzen/boerse/aktien/ siemens /china_aid_69754.html (accessed on 20 July 2021).

43. Siemens Mobility. Technical Specifications. Available online: https://www.mobility.siemens.com/global/en/portfolio/rail/ rolling-stock/components-and-systems/traction-motors.html (accessed on 20 July 2021).

44. Aerotask. Airbus A319 A320 A321 Technische Daten. Available online: https://aerotask.de/airbus-a319-a320-a321-technischedaten-beschreibung/ (accessed on 20 July 2021).

45. REMOS Aircraft GmbH. Flughandbuch Remos G-3/600. Eschelbach. Available online: https://www.flugplatz-edlc.de/ downloads/FHB_REMOS_G3_600_Rev01.pdf (accessed on 5 October 2021).

46. MAN. MAN Engines for Railway Applications. Available online: https://www.engines.man.eu/global/en/off-road/rail/ overview / Overview.html (accessed on 20 July 2021).

47. Cummins Inc. Engines for Passenger Vessels. Available online: https://www.cummins.com/engines/marine-passenger (accessed on 20 July 2021).

48. Schindler, C.; Brandhorst, M.; Dellmann, T. Handbuch Schienenfahrzeuge_Entwicklung, Produktion, Instandhaltung, 1st ed.; Eurailpress: Hamburg, Germany, 2014.

49. Lajunen, A.; Sainio, P.; Laurila, L.; Pippuri-Mäkeläinen, J.; Tammi, K. Overview of powertrain electrification and future scenarios for non-road mobile machinery. Energies 2018, 11, 1184. [CrossRef]

50. Ding, Y.; Cano, Z.P.; Yu, A.; Lu, J.; Chen, Z. Automotive Li-Ion batteries: Current status and future perspectives. Electrochem. Energy Rev. 2019, 2, 1-28. [CrossRef]

51. International Energy Agency IEA. Global EV Outlook 2020: Entering the Decade of ELECTRIC Drive? Available online: https: / / webstore.iea.org/global-ev-outlook-2020 (accessed on 5 October 2021).

52. E4tech. The Fuel Cell Industry Review. 2019. Available online: www.FuelCellIndustryReview.com. (accessed on 5 October 2021).

53. Cano, Z.P.; Banham, D.; Ye, S.; Hintennach, A.; Lu, J.; Fowler, M.; Chen, Z. Batteries and fuel cells for emerging electric vehicle markets. Nat. Energy 2018, 3, 279-289. [CrossRef]

54. Joint Research Center, Directorate-General Mobility and Transport. State of the Art on Alternative Fuels Transport Systems in the European Union; Europian Parlament: Luxembourg, 2020. [CrossRef]

55. Sterling PBES Energy Solutions. Aurora \& Tycho Brahe Electric Ferries. Available online: https://spbes.com/portfolio/electricferry-aurora/ (accessed on 7 September 2020).

56. Berjoza, D.; Jurgena, I. Influence of batteries weight on electric automobile performance. Eng. Rural Dev. 2017, 16, 1388-1394.

57. FuelsEurope. Vision 2050 a Pathway for the Evolution of the Refining Industry and Liquid Fuels; FuelsEurope: Brussels, Belgium. Available online: https:/ / www.fuelseurope.eu/publication/vision-2050-pathway-evolution-refining-industry-liquid-fuels / (accessed on 5 October 2021).

58. Scheier, B.; Meirich, C.; Dittus, H.; Böhm, M. Stand der Technik von Antriebskonzepten für Rangier- und Streckenlokomotiven. Eisenb. Rundsc. 2018, 67, 51-56.

59. Oszfolk, B.; Radke, M.; Ibele, Y. Hybridantrieb stellt Marktreife unter Beweis. ETR Eisenb. Rundsc. 2015, 9, 45-48. 
60. CENELEC. EN 62864: Railway Applications—Rolling Stock: Power SUPPLY with Onboard Energy Storage System; CENELEC: Brussels, Belgium, 2016.

61. International Electrotechnical Commission. IEC 62928: 2017 Railway Applications—Rolling Stock—Onboard Lithium-Ion Traction Batteries; International Electrotechnical Commission: Geneva, Switzerland, 2017.

62. Battery University. BU-205: Types of Lithium-Ion. Available online: https://batteryuniversity.com/article/bu-205-types-oflithium-ion (accessed on 2 November 2020).

63. Allen, T. Hybrid \& Electric: Fork in the Path? Available online: https:/ / www.khl.com/1133585.article (accessed on 19 July 2021).

64. Stranger, J. EST-Floattech Delivers ESS to 8 Caterpillar, 25 Tonne, Zero-Emission Excavators. EST Floattech. Available online: https:/ / www.est-floattech.com/est-floattech-delivers-ess-to-8-caterpillar-25-tonne-zero-emission-excavator/ (accessed on 19 July 2021).

65. Epiroc. Elektrisch Betriebene Untertage-Lader. Available online: https://www.epiroc.com/de-at/products/loaders-and-trucks/ electric-loaders (accessed on 19 July 2021).

66. Moore, K. MacLean Engineering-Interest in Electric Mining Vehicles Turning into Purchase Orders. Available online: https: / / resourceworld.com/maclean-engineering-interest-in-electric-mining-vehicles-turning-into-purchase-orders / (accessed on 19 July 2021).

67. Suncar. Elektrobagger-Modelle. Available online: https:/ /www.suncar-hk.com/files/brochure-TB1140E.pdf (accessed on 19 July 2021).

68. Akasol. Akasystem 15 AKM 46 POC. Available online: https://www.akasol.com/library/Downloads/Datenblätter/19-05-2021 /AK_Datenblatt_AKASystem_15-AKM-46-POC_2021_EN.pdf (accessed on 19 July 2021).

69. Mecalac. MECALAC e12: A 100\%-Electric Excavator for Urban Building Sites. Available online: https:/ /www.mecalac.com/es/ noticias-y-eventos/mecalac-e12-electric-wheel-excavator.html (accessed on 19 July 2021).

70. Turkka, K. The Clean Team. Available online: https://solidground.sandvik/the-clean-team/ (accessed on 19 July 2021).

71. Aragonès, M.P.; Serafimova, T. Zero Emission Construction Sites: The Possibilities and Barriers of Electric Construction Machinery. Available online: https:/ / bellona.org/publication/zero-emission-construction-sites-the-possibilities-and-barriers-of-electricconstruction-machinery (accessed on 5 October 2021).

72. Equipment Today. (VIDEO) Hyundai and Cummins Inc. Collaborate on Electric Prototype R35E Compact Excavator. Available online: https://www.forconstructionpros.com/equipment/earthmoving-compact/mini-excavators/video/21090225/videohyundai-and-cummins-inc-collaborate-on-electric-prototype-r35e-compact-excavator (accessed on 19 July 2021).

73. Bellona. Database: Emission-Free Construction Equipment (by Product Type). Available online: https://bellona.org/databaseemission-free-construction-equipment-by-product-type (accessed on 11 September 2020).

74. Mecalac. Technical Specs-12 MTX Mecalac. Available online: https://www.lectura-specs.com/en/model/constructionmachinery/wheel-excavators-mecalac/12-mtx-1050346 (accessed on 19 July 2021).

75. Synák, F.; Čulík, K.; Rievaj, V.; Gaňa, J. Liquefied petroleum gas as an alternative fuel. Transp. Res. Proc. 2019, 40, 527-534. [CrossRef]

76. Cheshier, G.; Roy, B. Compressed Natural Gas Short Line Locomotive Study; NYSERDA: Albany, NJ, USA, 2016. Available online: https: / / www.nyserda.ny.gov/- / media/Files/Publications/Research/Transportation/16-36-Compressed-Natural-GasShort-Line-Accessible.pdf (accessed on 5 October 2021).

77. DG MOVE-Expert Group on Future Transport Fuels. State of the Art on Alternative Fuels Transport Systems in the European Union. Available online: http:/ / ec.europa.eu/transport/sites/transport/files/themes/urban/studies/doc/2015-07-alter-fuelstransport-syst-in-eu.pdf (accessed on 5 October 2021).

78. Ambaye, T.G.; Vaccari, M.; Bonilla-Petriciolet, A.; Prasad, S.; van Hullebusch, E.D.; Rtimi, S. Emerging technologies for biofuel production: A critical review on recent progress, challenges and perspectives. J. Environ. Manag. 2021, 290, 112627. [CrossRef] [PubMed]

79. Nguyen, V.N.; Blum, L. Syngas and synfuels from $\mathrm{H}_{2} \mathrm{O}$ and $\mathrm{CO}_{2}$ : Current status. Chem. Ing. Tech. 2015, 87, 354-375. [CrossRef]

80. Schulz, S.C. Synthetische Kraftstoffe: Vor- und Nachteile der Diesel-Alternative. Available online: https://utopia.de/ratgeber/ synthetische-kraftstoffe-vor-und-nachteile-der-diesel-alternative/ (accessed on 13 September 2020).

81. International Energy Agency IEA. The Future of Hydrogen Seizing Today's Opportunities; Report prepared by the IEA for the G20, Japan. Available online: https:/ / webstore.iea.org/download/direct/2803) (accessed on 5 October 2021).

82. Ortega Hortelano, A.; van Balen, M.; Gkoumas, K.; Haq, G.; Tsakalidis, A.; Grosso, M.; Pekár, F. Research and Innovation in Low Emission Alternative ENERGY for Transport; EUR 29936 EN; Publications Office of the European Union: Luxembourg, 2019. [CrossRef]

83. Samsun, R.C.; Antoni, L.; Rex, M. Report on Mobile Fuel Cell Application: Tracking Market Trends. Available online: https: //www.ieafuelcell.com/index.php?id=5\#c280 (accessed on 5 October 2021).

84. European Commission. European Alternative Fuels Observatory (EAFO). Available online: https://www.eafo.eu (accessed on 4 September 2020).

85. European Automobile Manufacturers Association. Report-Vehicles-in-Use. Available online: https://www.acea.be/statistics / article/Report-Vehicles-in-use (accessed on 10 September 2020).

86. European Alternative Fuels Observatory EAFO. EAFO Analysis. March 2020. Available online: www.eafo.eu (accessed on 5 October 2021). 
87. International Union of Railway UIC. Railway Statistics Synopsis 2020 Edition. Available online: https://uic.org/supportactivities/statistics/ (accessed on 5 October 2021).

88. Study Task Force of the Hydrogen Council. Hydrogen Scaling Up: A Sustainable Pathway for the Global Energy Transition. Available online: http:/ /hydrogencouncil.com/wp-content/uploads/2017/11/Hydrogen-scaling-up-Hydrogen-Council.pdf (accessed on 5 October 2021).

89. Adolf, J.; Balzer, C.H.; Louis, J.; Schabla, U.; Fischedick, M.; Arnold, K.; Pastowski, A.; Schüwer, D. Energie der Zukunft? Nachhaltige Mobilität durch Brennstoffzelle und H2. Shell Wasserstoff-Studie; Bundesanstalt für Straßenwesen (BASt): Bergisch Gladbach, Germany, 2017. [CrossRef]

90. SCI Verkehr GmbH. Railway Electrification_Global Market Trends. Available online: https://www.sci.de/fileadmin/user_ upload/MC_Studien_Flyer/180425_Flyer_MC_Electrification_en.pdf (accessed on 5 October 2021).

91. SCI Verkehr GmbH. Diesel Locomotives_Global Market Trends. Available online: https://www.sci.de/fileadmin/user_upload/ MC_Studien_Flyer/Flyer_Diesel_Locomotives_dt.pdf (accessed on 5 October 2021).

92. Blumenfeld, M.; Wemakor, W.; Azzouz, L.; Roberts, C. Developing a new technical strategy for rail infrastructure in low-income countries in Sub-Saharan Africa and South Asia. Sustainability 2019, 11, 4319. [CrossRef]

93. International Energy Agency IEA, International Union of Railways UIC. The Future of Rail. Available online: https://www.iea. org/futureofrail/ (accessed on 5 October 2021).

94. Lawrenz, D. Bombardier: Traxx AC3 Last Mile-Lok: Typzulassung in Bulgarien und Kroatien. Available online: https: / / eisenbahn-kurier.de/index.php/4296-bombardier-traxx-ac3-last-mile-lok-erhaelt-offizielle-typzulassung-in-bulgarienund-kroatien (accessed on 19 October 2020).

95. Railway Pro. Occitanie Region Receives the 300th Coradia Polyvalent Train. Railway Pro. Available online: https://www. railwaypro.com/wp/occitanie-region-receives-the-300th-coradia-polyvalent-train/ (accessed on 19 October 2020).

96. Ersahin, I.; Leyendecker, W. Die erste Hybrid-Rangierlokomotive der türkischen Lokomotivfabrik Tülomsas. Der Eisenbahningenieur 2019, 44-45.

97. Fröhlich, M. Energy Storage on Board of Rail Vehicles. In Local Renewables; Bombardier: Freiburg, Germany, 2010; Available online: https:/ / web.archive.org/web/20140226172716/http:/ /www.local-renewables-conference.org/fileadmin/lr-conference/ files/LR2010/Documents /A1_Bombardier_Freiburg_Oct_2010.pdf (accessed on 5 October 2021).

98. Railway Gazette International. Rhein-Neckar Verkehr Orders More Supercapacitor Trams. Available online: https://www. railwaygazette.com/rhein-neckar-verkehr-orders-more-supercapacitor-trams/35818.article (accessed on 6 September 2021).

99. Railway Gazette International. Supercapacitors to be Tested on Paris STEEM Tram. Available online: https:/ / www.railwaygazette. com/supercapacitors-to-be-tested-on-paris-steem-tram/34187.article (accessed on 6 September 2021).

100. Flerlage, H.; Mazzone, A.; von Mach, S. Neue fahrzeugfunktionen durch den batteriebetrieb von schienenfahrzeugen mit speichern hoher leistung und optimiertem energiemanagement. ZEV Rail Tag. SFT Graz 2017, 2017, $120-127$.

101. Mallikat, J. Alternative antriebstechnologien für schienenfahrzeuge. Eisenbahningenieur 2019, 38-43.

102. SCI Verkehr GmbH. Diesel and Alternative Drive Locomotives-Global Market Trends 2020. Available online: https:/ /www.sci. de/shop/search/product/?productid=1dfc2224-045e-440d-9c3c-8c8fc6613dc6\&L=1 (accessed on 13 September 2020).

103. Wang, J.; Yang, Z.; Liu, S.; Zhang, Q.; Han, Y. A comprehensive overview of hybrid construction machinery. Adv. Mech. Eng. 2016, 8,1687814016636809 . [CrossRef]

104. He, X.; Jiang, Y. Review of hybrid electric systems for construction machinery. Autom. Constr. 2018, 92, 286-296. [CrossRef]

105. Poirier, S.; Lacroix, R.; Ouellette, S. The "Scoop" on the world's first hybrid mining loader. S. Afr. Inst. Min. Metall. Narrow Vein Reef 2008, 2008, 1-9.

106. >DNV GL. Perspectives on Zero Emission Construction. Available online: http://www.sustainable-procurement.org/fileadmin/ user_upload/layout/homepage/NGO_Network/2.4_-_BestPractice_-_Omsorgsbygg_Oslo.pdf (accessed on 5 October 2021).

107. SINTEF. NASTA og SINTEF Skal Utvikle Utslippsfrie Gravemaskiner. Available online: https://www.sintef.no/siste-nytt/nastaog-sintef-skal-utvikle-utslippsfrie-gravemaskiner/ (accessed on 10 September 2020).

108. Sander Poulsen, T. Market Analysis for Non-Road Mobile Machinery Sector. Available online: https://www.gate21.dk/wpcontent/uploads/2017/06/Market-Analysis-for-Non-Road-Mobile-Machinery-Sector_FINAL.pdf (accessed on 5 October 2021).

109. Volvo Construction Equipment. Electric Site Research Project. Available online: https://www.volvoce.com/global/en/this-isvolvo-ce/what-we-believe-in/innovation/electric-site/ (accessed on 19 July 2021).

110. DHL Global. DHL Express Shapes Future for Sustainable Aviation with the Order of First-Ever All-Electric Cargo Planes from Eviation. Available online: https://www.dhl.com/global-en/home/press/press-archive/2021/dhl-express-shapes-future-forsustainable-aviation-with-the-order-of-first-ever-all-electric-cargo-planes-from-eviation.html (accessed on 19 August 2021).

111. Wang, W.-C.; Tao, L.; Markham, J.; Zhang, Y.; Tan, E.; Batan, L.; Warner, E.; Biddy, M. Review of Biojet Fuel Conversion Technologies; National Renewable Energy Laboratory: Denver, CO, USA, 2016. Available online: https://www.nrel.gov/docs/fy16osti/66291. pdf (accessed on 5 October 2020).

112. International Energy Agency IEA. Energy Technology Perspectives 2020; IEA: Paris, France, 2020. [CrossRef]

113. DNV GL. Assessment of Selected Alternative Fuels and Technologies; DNV GL: Bærum, Norway, 2019.

114. Water-Go-Round. Water-Go-Round Project. Available online: https://watergoround.com/ (accessed on 10 September 2020).

115. Reuter, M.; Waschek, S. AIDA Cares 2019; AIDA: Rostock, Germany, 2019; Available online: https://www.aida.de/en/aidacruises / responsibility / aida-cares-2017.34504.html (accessed on 5 October 2021). 
116. European Commission. Alternative Fuels for Sustainable Mobility in Europe. Available online: https://ec.europa.eu/transport/ themes/urban/cpt_en (accessed on 19 October 2020).

117. Mueller, A. Wissenschaftliche Bewertung von Alternativen, Emissionsarmen Antriebskonzepten für den Bayerischen SPNV. Available online: https://beg.bahnland-bayern.de/de/aktuelles/gutachten-alternative-antriebe-im-bahnland-bayern (accessed on 5 October 2021).

118. Hoffmann, M.; Dittus, H.; Falabretti, M.; Pagenkopf, J.; Böhm, M. Alternative antriebskonzepte für rangierfahrzeuge und baufahrzeuge der schweizerischen bundesbahnen SBB. ZEVRail 2017, 125-133.

119. International Energy Agency IEA. Hybrid and Electric Vehicles: The Electric Drive Hauls. Available online: http://www.ieahev. org/assets /1/7/Report2019_WEB_New_(8).pdf (accessed on 5 October 2021).

120. Green, J.M.; Hartman, B.; Glowacki, P.F. A system-based view of the standards and certification landscape for electric vehicles. In Proceedings of the EVS 2016 - 29th International Electric Vehicle Symposium, Montreal, QC, Canada, 19-22 June 2016; pp. 564-575.

121. Pelzl, C. Neues System für Flächendeckende Verfügbarkeit von Grünem Wasserstoff. Available online: https://www.tugraz.at/ tu-graz/services/news-stories/medienservice/einzelansicht/article/neues-system-fuer-flaechendeckende-verfuegbarkeitvon-gruenem-wasserstoff/ (accessed on 5 September 2020).

122. Ruf, Y.; Zorn, T.; De Neve, P.A.; Andrae, P.; Erofeeva, S.; Garrison, F.; Schwilling, A. Study on the Use of Fuel Cells and Hydrogen in the Railway Environment. Available online: https:/ / shift2rail.org/publications/study-on-the-use-of-fuel-cells-and-hydrogenin-the-railway-environment/ (accessed on 5 October 2021).

123. Rajasegar, R.; Mitsingas, C.M.; Mayhew, E.K.; Liu, Q.; Lee, T.; Yoo, J. Development and characterization of additive-manufactured mesoscale combustor array. J. Energy Eng. 2018, 144, 04018013. [CrossRef]

124. European Federation for Transport and Environment AISBL. Do Gas Trucks Reduce Emissions? Available online: https://www. transportenvironment.org/sites/te/files/publications/2019_09_do_gas_trucks_reduce_emissions_paper_EN.pdf (accessed on 5 October 2021).

125. Baumann, K. LNG-Activities in Dutch-German Cooperation (MariTIM, LNG-Initiative Nordwest, WattenStart). In Proceedings of the 4th Annual Global LNG Forum, London, UK, 3-4 February 2014; Available online: https:/ / docplayer.net/39940871-Lngactivities-in-dutch-german-cooperation-maritim-lng-initiative-nordwest-wattenstart-katja-baumann-mariko-gmbh-germany. html (accessed on 5 October 2021).

126. Lenz, M. Natural Gas Goes on Trial. Int. Railway J. 2014. Available online: https://www.railjournal.com/in_depth/natural-gasgoes-on-trial (accessed on 19 July 2021).

127. Zasiadko, M. Russia Tests New LNG-Powered Locomotive. Available online: https://www.railtech.com/rolling-stock/ 2020/02/17/russia-tests-new-lng-powered-locomotive $/$ ?utm_source=newsletter\&utm_medium=email\&utm_campaign= Newsletterweek2020-08\&gdpr=accept (accessed on 13 October 2020).

128. Ivanov, B. About experience history biofuels in Russian railways and the time of the diesel locomotives. In The End of Fossil Fuels; UIC Workshop Zürich: Zürich, Switzerland, 2019.

129. Howarth, R.W. A bridge to nowhere: Methane emissions and the greenhouse gas footprint of natural gas. Energy Sci. Eng. 2014, 2, 47-60. [CrossRef]

130. Stephan, A.; Wittemann, N.T.; Müller, A. Alternative antriebskonzepte: Welcher hybrid für welche strecke? Eisenbahningenieur 2018, 9, 60-66.

131. Capcomp GmbH. Supercap vs. Batterie. Available online: https://www.capcomp.de/kondensatoren/vergleich-ultracap-akku. html (accessed on 22 July 2021).

132. Bégun, F.; Frackowiak, E. Supercapacitors; Wiley-VCH: Weinheim, Germany, 2013. 